\title{
Synthesis, Physiochemical Properties, Photochemical Probe, and Antimicrobial Effects of Novel Norfloxacin Analogues
}

\author{
Dina A. Bakhotmah, ${ }^{1}$ Reda M. Abdul-Rahman, ${ }^{2}$ Mohammad S. Makki, ${ }^{2}$ \\ Mohamed A. El-Zahabi, ${ }^{3}$ and Mansor Suliman ${ }^{4}$ \\ ${ }^{1}$ Joint Supervision Program, King Abdulaziz University, P.O. Box 80215, Jeddah 21589, Saudi Arabia \\ ${ }^{2}$ Department of Chemistry, Faculty of Sciences, King Abdul-Aziz University, P.O. Box 80203, Jeddah 21589, Saudi Arabia \\ ${ }^{3}$ Department of Organic Chemistry, Faculty of Pharmacy, King Abdul-Aziz University, Jeddah 21589, Saudi Arabia \\ ${ }^{4}$ Department of Pharmacology, Faculty of Medicine, King Abdul-Aziz University, Jeddah 21589, Saudi Arabia
}

Correspondence should be addressed to Dina A. Bakhotmah, d.bakhotmah@yahoo.com

Received 19 December 2010; Accepted 10 January 2011

Academic Editor: G. Li

Copyright (C 2011 Dina A. Bakhotmah et al. This is an open access article distributed under the Creative Commons Attribution License, which permits unrestricted use, distribution, and reproduction in any medium, provided the original work is properly cited.

\begin{abstract}
The emerging resistance to antimicrobial drugs demands the synthesis of new remedies for microbial infections. Attempts have been made to prepare new compounds by modifications in the quinolone structure. An important method for the synthesis of new quinolone is using Vilsmeier approach but has its own limitations. The present work aimed to synthesize novel norfloxacin analogues using modified Vilsmeier approach and conduct preliminary investigations for the evaluation of their physicochemical properties, photochemical probe, and antimicrobial effects. In an effort to synthesize norfloxacin analogues, only 7-bromo-6N-benzyl piperazinyl-4-oxoquinoline-3-carboxylic acid was isolated using Vilsmeier approach at high temperature, where $N, N^{\prime}-$ bis-(4-fluoro-3-nitrophenyl)-oxalamide and $N, N^{\prime}$-bis-(3-chloro-4-fluorophenyl)-malonamide were obtained at low temperature. Correlation results showed that lipophilicity, molecular mass, and electronic factors might influence the activity. The synthesized compounds were evaluated for their antimicrobial effects against important pathogens, for their potential use in the inhibition of vitiligo.
\end{abstract}

\section{Introduction}

The structure activity relationship (SAR) for the quinolone skeleton 1-alkyl-1,4-dihydro-4-oxo-quinoline-3-carboxylic acid studies revealed that the 6-halogen atom, especially the 6-fluorine, is responsible for the potency as represented by the binding capacity with DNA gyrase and topoisomerase IV [1]. It is clear that chemical modifications at C-7 are suitable to control the pharmacokinetic properties and, hence, changes in the cell permeability of these antibiotics. $\mathrm{N}$ piperazinyl derivatives of fluoroquinolones were introduced and demonstrated for various biological activities that possess broad-spectrum activity [2-6]. Furthermore, it is clear that the neutral species of fluoroquinolones are more lipophilic than the Zwitterionic form. Therefore, factors that can affect $N$-protonation like steric and electronic effect or charge density can also affect lipophilicity [7-9].
Procopiou et al. [10] prepared a series of asymmetrical 1,4-disubstituted piperazines as a novel class of non-brainpenetrant histamine $\mathrm{H} 3$ receptor antagonists. In addition, Foroumadi et al. [11] synthesized a modified norfloxacin via heteroarylation of norfloxacin on $N$-piperazinyl position (Scheme 1). The antibacterial activity of these modified norfloxacin depends not only on the bicyclic heteroaromatic pharmacophore but also on the nature of the peripheral substitutions and their spatial relationship, such as solubility, thermal stability, hydrolysis, and a possibility to form a Zwitter ion. Meth-Cohn and Taylor [12] reported an important method for the synthesis of quinolones using reverse Vilsmeier approach but has its own limitations, like uncompleted cyclisation to the target quinolone.

In the light of these observations, the aim of this work was to synthesize novel norfloxacin analogues using modified Vilsmeier approach and conduct preliminary investigations 


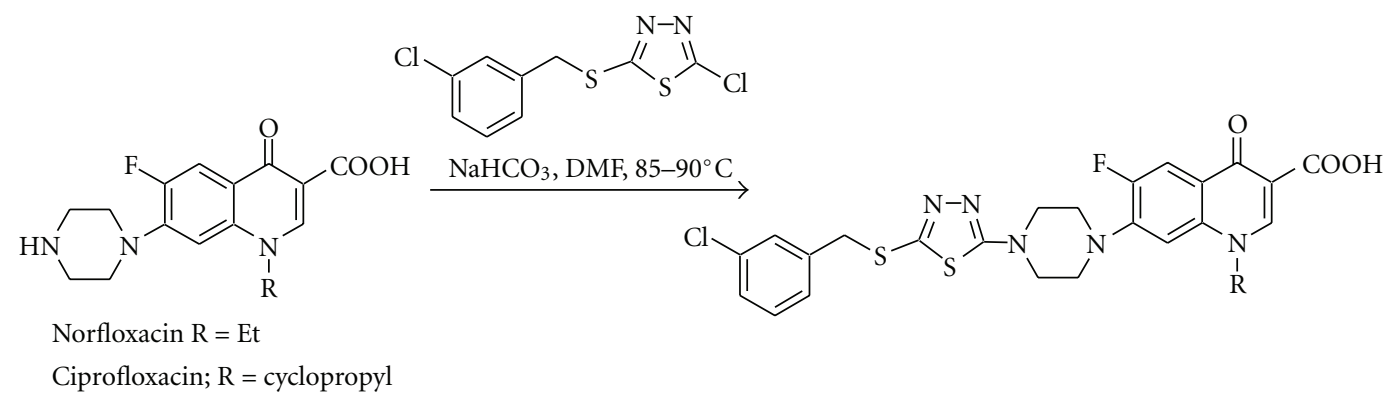

SCHEME 1: Norfloxacin modification.

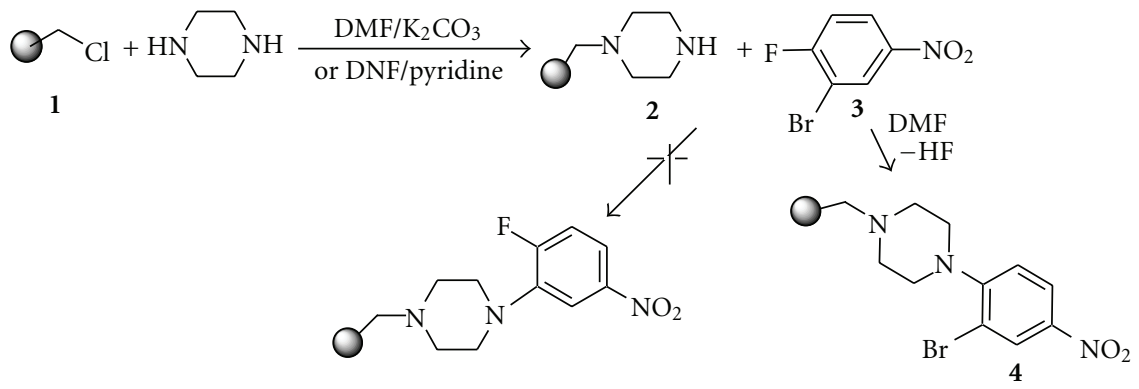

SCHeme 2

for the evaluation of their physicochemical properties, photochemical probe, and antimicrobial effects.

\section{Materials and Methods}

2.1. Equipment Used for the Characterization of the Produced Compounds. Electrothermal 9100 (fisher Scientific, US) was used to determine melting points or ranges. Infrared (IR) spectra were recorded on a Unicam Research Series 2000 FTIR. NMR spectra were recorded in $\mathrm{DMSO}$ or $\mathrm{CDCl}_{3}$ on a Bruker AVANCE 300 at $300 \mathrm{MHz}$. Mass spectrometry was performed on an Esquire 3000 plus, or Bruker ApexII, for low and high resolution. Elemental analysis was performed on an Exeter Analytical CE-440; GCMS was performed on Shimadzu GC-17A and QP-5000 Mass Spectrometer.

2.2. Materials Used for Microbiological Assay. Nutrient Agar, MacConkey Agar, Sabouraud Dextrose Agar, and dimethylformamide (DMF) were obtained from Sigma; Nalidixic acid $(30 \mu \mathrm{g} /$ disk, Bioanalize, Egypt) and Nystain (manufactured by Pasteur Lab., Egypt, NS 100 units (100 $\mu \mathrm{g} /$ disk) were used as reference antibiotics.

2.3. Synthesis of Norfloxacin Analogues. We used a solid phase via Merrifield resin through reactions of substituted piperazine with 3-bromo-4-fluoronitrobenzene. In the synthetic sequence, the Merrifield resin (1) was first suspended in dry DMF, and to this suspension was added an excess of piperazine (2-3 equivalents) in pyridine or anhydrous $\mathrm{K}_{2} \mathrm{CO}_{3}$ (6-8 equivalents). The reaction mixture was continued at $40^{\circ} \mathrm{C}$ for 24 hours then piperazine resin (2) was obtained, filtered, washed with $\mathrm{CH}_{2} \mathrm{Cl}_{2}$, and dried. Compound 2 was resuspended in DMF and reacted with 3-bromo-4-fluoronitrobenzene (3) to give the 4-piperazine resin-supported-3-bromo-1-nitrobenzene (4) (not the expected 3-piperazine resin-supported-4-fluoro-1nitrobenzene), (Scheme 2), which on reduction with $\mathrm{SnCl}_{2}$ EtOH yielded the 3-bromo-4-(4'-resin-supported benzyl piperazinyl)-1-aniline (5) and then by treatment with an excess of formic acid at room temperature for 12 hours produced the corresponded 3-bromo-4-(4'-resinsupported benzyl piperazinyl)-1-formanild (6). The dry resin-supported formanilide 6, when reacted with Phosphorus oxychloride or Oxalyl chloride and methyl malonyl chloride (7) under reverse Vilsmeier conditions, mainly gave the resin-supported quinolone, 6-fluoro-7-piperazino4-oxo-3-quinolone carboxylic acid, (8) (Scheme 3). The procedure, in general, yielded a mixture of by-products in low quantities, and TLC and GCMS were used for the assessment of the recovered cleavage products.

2.4. Preparation of 3-bromo-4-fluoronitrobenzene (3). Equimolar mixture of nitric acid and sulphuric acid (1:1, $25 \mathrm{~mL}: 25 \mathrm{~mL}$ ) was stirred at $\sim 5^{\circ} \mathrm{C}$. A solution of 2 fluorobromobenzene $(25 \mathrm{~g}, 0.143 \mathrm{moL})$ in methanol $(30 \mathrm{~mL})$ was added to the mixture with gradual stirring over a period of 20-30 minutes. After complete addition, the temperature was raised gradually to $70^{\circ} \mathrm{C}$ for $1 \mathrm{~h}$. After cooling, the reaction mixture was poured into cold water $(20 \mathrm{~mL})$, and 


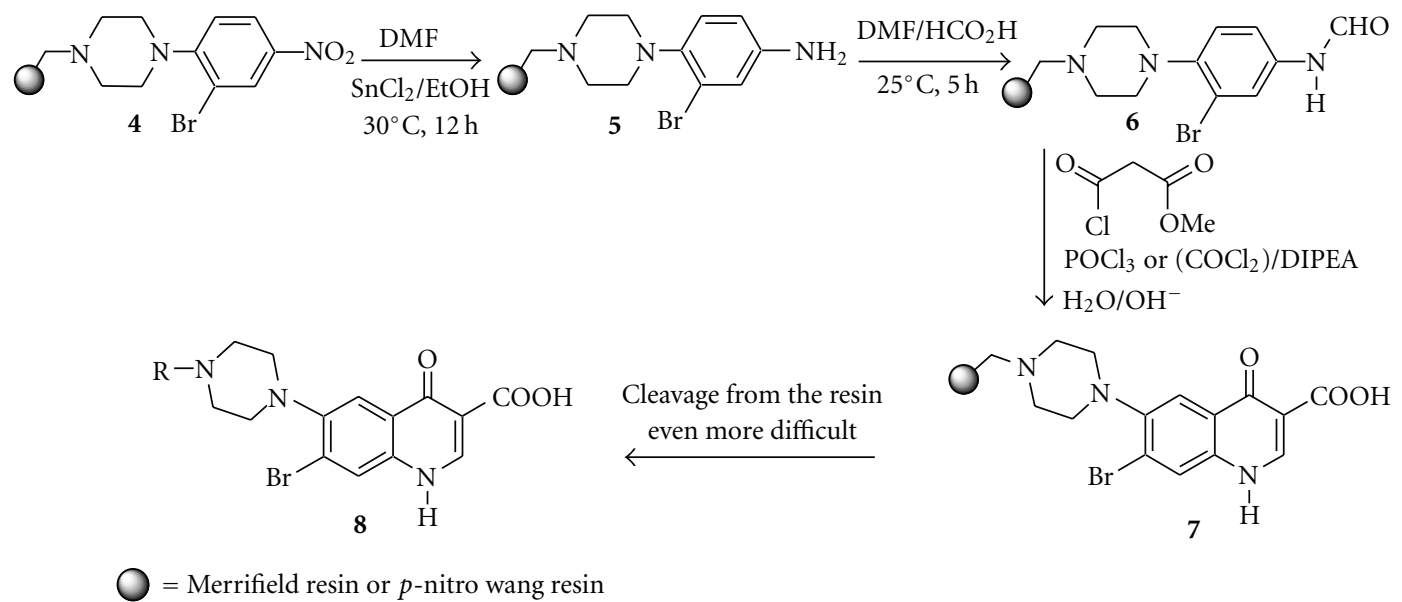

Scheme 3

the immediate cream solid precipitate was collected by filtration. Crystallization with $\mathrm{CHCl}_{3}$ gave a cream shiny crystals $\left(29.23 \mathrm{~g}, 93 \%\right.$ yield), $\mathrm{mp} 60-62^{\circ} \mathrm{C}$ (lit. [13] $\mathrm{mp}$ $\left.58-59^{\circ} \mathrm{C}\right) ; \nu_{\max } / \mathrm{cm}^{-1} 1535$ and $1342\left(\mathrm{NO}_{2}\right) ; \delta_{\mathrm{H}}(300 \mathrm{MHz}$; $\left.\mathrm{CDCl}_{3}\right) 7.29(1 \mathrm{H}, \mathrm{t}, J=6.0 \mathrm{~Hz}, \mathrm{H}-5), 8.24(1 \mathrm{H}, \mathrm{m}, \mathrm{H}-6)$, $8.50(1 \mathrm{H}, \mathrm{dd}, J=2.0$ and $4.3 \mathrm{~Hz}, \mathrm{H}-2)$; $\delta_{\mathrm{C}}\left(75 \mathrm{MHz} ; \mathrm{CDCl}_{3}\right)$ $110.1(\mathrm{~d}, J=22.5 \mathrm{~Hz}, \mathrm{C}-3), 117.1(\mathrm{~d}, J=22.5 \mathrm{~Hz}, \mathrm{C}-5)$, 123.3 (d, $J=7.5 \mathrm{~Hz}, \mathrm{C}-6), 129.6$ (C-2), 144.4 (C-1), 162.9 $\left(\mathrm{d}, J_{\mathrm{C}-\mathrm{F}}=195.7 \mathrm{~Hz}, \mathrm{C}-4\right) ; \delta \mathrm{F}(\mathrm{MHz} ; \mathrm{CDCl} 3)-74.22(\mathrm{~s}) ; \mathrm{m} / z$ 221( $\left.\mathrm{M}^{+}, 44 \%\right), 219\left(\mathrm{M}^{+}, 46 \%\right), 203$ (3), 189 (17), 173 (38), 161 (14), 94 (M-Br- $\left.\mathrm{NO}_{2}, 100\right), 68$ (25), 61 (7), 50 (38).

2.5. Preparation of 4-(4'-benzylpiperazin-1'-yl)-3-bromo1-nitrobenzene (9). Under dry conditions, 3-bromo-4fluoronitrobenzene (3) $(5.1 \mathrm{~g}, 23 \mathrm{mmoL})$ was dissolved in dry acetonitrile $(2 \mathrm{~mL})$, then anhydrous $\mathrm{K}_{2} \mathrm{CO}_{3}(9.6 \mathrm{~g}$, $69.2 \mathrm{mmoL}$ ) was added followed by addition of $\mathrm{N}$ benzylpiperazine $(8 \mathrm{~g}, 46 \mathrm{mmoL})$ to the suspension mixture using a syringe; the temperature gradually raised to reflux for $12 \mathrm{~h}$ (or until the complete disappearance of the starting material). The reaction was monitored by TLC $\left(\mathrm{CHCl}_{3}\right.$ : petroleum ether (40-60), 50\%). The acetonitrile was removed under vacuo, and the resulting solid was stirred in cold water $(200 \mathrm{~mL})$ for 20 minutes. The pale brown solid formed was recrystallized from $\mathrm{CHCl}_{3}$ to give bright yellow needle-like crystals of 9 (5.8 g, 81\% yield), mp $123-124^{\circ} \mathrm{C}$; $\left[\mathrm{C}_{17} \mathrm{H}_{18} \mathrm{BrN}_{3} \mathrm{O}_{2}\right.$ Calc. C, 54.3; H, 4.8; N, 11.2. Found C: $54.5 ; \mathrm{H}, 4.8 ; \mathrm{N}, 11.1] ; \nu_{\max } / \mathrm{cm}^{-1} 1580$, and $1339\left(\mathrm{NO}_{2}\right)$; $\delta_{\mathrm{H}}\left(300 \mathrm{MHz} ; \mathrm{CDCl}_{3}\right), 2.57\left(4 \mathrm{H}, \mathrm{m}, \mathrm{H}-3^{\prime}\right.$, and $\left.\mathrm{H}-5^{\prime}\right), 3.17$ $\left(4 \mathrm{H}, \mathrm{m}, \mathrm{H}-2^{\prime}\right.$ and $\left.\mathrm{H}-6^{\prime}\right), 3.56\left(2 \mathrm{H}, \mathrm{s}, \mathrm{Ph}-\mathrm{CH}_{2}\right), 7.12(1 \mathrm{H}, \mathrm{d}$, $J=9.0 \mathrm{~Hz}, \mathrm{H}-5), 7.24(5 \mathrm{H}, \mathrm{m}, \mathrm{Ph}), 8.08(1 \mathrm{H}, \mathrm{dd}, J=2.7$ and $9.0 \mathrm{~Hz}, \mathrm{H}-6), 8.26(1 \mathrm{H}, \mathrm{d}, J=2.7 \mathrm{~Hz}, \mathrm{H}-2) ; \delta_{\mathrm{C}}(75 \mathrm{MHz}$; $\left.\mathrm{CDCl}_{3}\right) 51.1\left(\mathrm{C}-3^{\prime}\right.$ and $\left.\mathrm{C}-5^{\prime}\right), 52.8\left(\mathrm{C}-2^{\prime}\right.$ and $\left.\mathrm{C}-6^{\prime}\right), 62.4$ $\left(\mathrm{CH}_{2}-\mathrm{Ph}\right), 116.9$ (C-3), 121.1 (C-5), 124.7 (C-6), 127.5 (C2), $129.5(\mathrm{Ph}), 142.3$ (C-1), 156.6 (C-4); $m / z\left(\mathrm{M}^{+} 373 / 375\right)$.

2.6. Preparation of 4-(4'-benzylpiperazin-1'-yl)-3-bromo-4phenylamine (10) [14]. A pale yellow oil (2.7 g, 60\% yield); $v_{\max } \mathrm{cm}^{-1} 3150\left(\mathrm{NH}_{2}\right) ; \delta_{\mathrm{H}}\left(300 \mathrm{MHz} ; \mathrm{CDCl}_{3}\right) 2.68(4 \mathrm{H}, \mathrm{s}$, $\mathrm{CH}_{2}-3^{\prime}$ and $\left.5^{\prime}\right)$ and $3.01\left(4 \mathrm{H}, \mathrm{s}, \mathrm{CH}_{2}-2^{\prime}\right.$ and $\left.6^{\prime}\right), 3.57(2 \mathrm{H}, \mathrm{s}$, $\left.\mathrm{Ph}-\mathrm{CH}_{2}\right), 6.62(1 \mathrm{H}, \mathrm{dd}, J=1.2$ and $4.2 \mathrm{~Hz}, \mathrm{H}-6), 6.94(1 \mathrm{H}$, $\mathrm{d}, J=4.2 \mathrm{~Hz}, \mathrm{H}-5), 6.97(1 \mathrm{H}, \mathrm{d}, J=1.2 \mathrm{~Hz}, \mathrm{H}-2), 7.37(5 \mathrm{H}$, $\mathrm{m}, \mathrm{Ph}) ; \delta_{\mathrm{C}}\left(75 \mathrm{MHz} ; \mathrm{CDCl}_{3}\right) 52.2\left(\mathrm{C}-3^{\prime}\right.$ and $\left.\mathrm{C}-5^{\prime}\right), 53.6(\mathrm{C}-$ $2^{\prime}$ and $\left.\mathrm{C}-6^{\prime}\right), 63.3\left(\mathrm{Ph}-\mathrm{CH}_{2}\right), 114.9(\mathrm{C}-3), 120.1(\mathrm{C}-6), 121.1$ (C-5), 121.8 (C-2), $128.4(\mathrm{Ph}), 142.3$ (C-1), 143.4 (C-4); HRMS (ESI). Found: $\mathrm{MH}^{+}, 346.0908$. Calc. for $\mathrm{C}_{17} \mathrm{H}_{20} \mathrm{BrN}_{3}$ : $\mathrm{MH}^{+}=346.0919$.

2.7. Preparation of 4-(4'-benzylpiperazin-1'-yl)-3-bromoformamide (11). Formic acid ( $5 \mathrm{~mL}, 0.13 \mathrm{moL}$ ) was added to 4-(4'-benzylpiperazin-1'-yl)-3-bromo-4-phenylamine (12) $(5 \mathrm{~g}, 14.4 \mathrm{mmoL})$, and the resulting clear solution was refluxed for $2 \mathrm{~h}$. After cooling to room temperature, the reaction mixture was poured into ice water $(10 \mathrm{~mL})$, then $\mathrm{NaHCO}_{3}$ solution $(10 \% \mathrm{w} / \mathrm{v}, 20 \mathrm{~mL})$ was added gradually until no more effervescence (formation of neutral to slightly basic solution) was observed and the solution extracted with $\mathrm{CH}_{2} \mathrm{Cl}_{2}$. $(3 \times 20 \mathrm{~mL})$. The organic layers were combined, washed with $\mathrm{NaHCO}_{3}$ solution $(10 \%, 20 \mathrm{~mL})$, and dried over $\mathrm{MgSO}_{4}$. The solvent was removed in vacuo until complete dryness to give $\mathbf{1 1}$ as a brown solid which was purified by column chromatography on silica, eluted with $\mathrm{CHCl}_{3}$ to give a white solid $(2.94 \mathrm{~g}, 54 \%), \mathrm{mp} 73-74^{\circ} \mathrm{C} ;\left[\mathrm{C}_{18} \mathrm{H}_{20} \mathrm{BrN}_{3} \mathrm{O}\right.$ Calc. C, 57.76; H, 5.39; N, 11.23. Found: C, 57.79; H, 5.41; $\mathrm{N}, 11.23] ; v_{\max } / \mathrm{cm}^{-1} 3320(\mathrm{br}, \mathrm{NH}), 1716(\mathrm{NCHO}) ; \delta_{\mathrm{H}}$ $\left(300 \mathrm{MHz} ; \mathrm{CDCl}_{3}\right) 2.68\left(4 \mathrm{H}\right.$, br s, $\mathrm{CH}_{2}-3^{\prime}$ and $\left.5^{\prime}\right), 3.06(4 \mathrm{H}$, br s, $\mathrm{CH}_{2}-2^{\prime}$ and $\left.6^{\prime}\right), 3.62\left(2 \mathrm{H}, \mathrm{s}, \mathrm{Ph}-\mathrm{CH}_{2}\right), 7.34(6 \mathrm{H}, \mathrm{m}$, $\mathrm{Ph}+\mathrm{H}-5), 7.48(1 \mathrm{H}, \mathrm{dd}, J=1.2$ and $4.2 \mathrm{~Hz}, \mathrm{H}-6), 7.81(1 \mathrm{H}$, $\mathrm{d}, J=1.2, \mathrm{H}-2), 8.34(1 \mathrm{H}, \mathrm{s}, \mathrm{CHO}), 8.58(1 \mathrm{H}, \mathrm{s}, \mathrm{NH})$; $\delta_{\mathrm{C}}\left(75 \mathrm{MHz} ; \mathrm{CDCl}_{3}\right) 51.7\left(\mathrm{C}-3^{\prime}\right.$ and $\left.\mathrm{C}-5^{\prime}\right), 53.2\left(\mathrm{C}-2^{\prime}\right.$ and C-6'), $63.2\left(\mathrm{Ph}^{\prime} \mathrm{CH}_{2}\right), 119.3$ (C-3), 120.1 (C-5), 121.0 (C-6), 125.5 (C-2), $129.4(\mathrm{C}-\mathrm{Ph}), 132.5$ and 132.8 (C-1), 147.7 and $148.5(\mathrm{C}-4), 158.9$ and $162.5(\mathrm{~N}-\mathrm{CHO})$.

2.8. Vilsmeier Reaction of 4-(4'-benzylpiperazin-1'-yl)-3bromoformanilide (9) and Formation of Compound 12. In 
dry atmosphere, a solution of 4-(4' -benzylpiperazin-1' -yl)3-bromoformamide (11) (1 g, $2.7 \mathrm{mmoL})$ in $\mathrm{POCl}_{3}(5 \mathrm{~mL})$ was stirred for 15 minutes at $25^{\circ} \mathrm{C}$. A solution of methyl malonyl chloride $(1.12 \mathrm{~g}, 8.5 \mathrm{mmoL})$ in $\mathrm{POCl}_{3}(2 \mathrm{~mL})$ was gradually added to the reaction mixture through a syringe. After addition was complete, the oil bath temperature was gradually raised to $130-140^{\circ} \mathrm{C}$, and the reaction was continued for $12 \mathrm{~h}$. The excess $\mathrm{POCl}_{3}$ was removed in vacuo, and the cooled black residue was dissolved in diethyl ether $(20 \mathrm{~mL})$, poured into ice $(50 \mathrm{~mL})$, and vigorously stirred for $2 \mathrm{~h}$. The resulting mixture was made basic by the addition of aq. $\mathrm{NaOH}$ solution $(30 \%, 10 \mathrm{~mL})$, refluxed for $2 \mathrm{~h}$, and cooled for $12 \mathrm{~h}$ in fridge $\left(<5^{\circ} \mathrm{C}\right)$. Column chromatography on the resulting black gum $\left(\mathrm{CHCl}_{3}: \mathrm{MeOH}\right.$, $90: 10)$ gave 6-(4'-benzylpiperazin-1'-yl)-7-bromo-4-oxo1,4-dihydro-quinoline-3-carboxylic acid (12). It was recrystallized from EtOH to produce a yellow solid as $(0.1 \mathrm{~g}, 5 \%$ yield); mp $285-286^{\circ} \mathrm{C} ; \nu_{\max } / \mathrm{cm}^{-1} 3525$ (carboxylic $\mathrm{OH}$ ), 1699 (carboxylic $\mathrm{C}=\mathrm{O}), 1611\left(\mathrm{COO}^{-}\right.$st as), $1462\left(\mathrm{COO}^{-}\right.$ st sy); $\delta_{\mathrm{H}}\left(600 \mathrm{MHz}\right.$; DMSO- $\left.d_{6}\right) 3.13(8 \mathrm{H}$, br s, piperazine), $4.19\left(2 \mathrm{H}, \mathrm{s}, \mathrm{Ph}-\mathrm{CH}_{2}\right), 7.45(5 \mathrm{H}, \mathrm{m}, \mathrm{Ph}), 7.83$ (1H, s, H-8), 8.15 (1H, s, H-5), 8.87 (1H, s, H-2), 15.21 (1H, br s, NH); $\delta_{\mathrm{C}} 51.21$ (piperazine), $60.0\left(\mathrm{CH}_{2}\right), 107.4(\mathrm{C}-3), 115.0(\mathrm{C}-$ 8), 124.4 (C-5), 124.6 (C-7), 126.1 (C-10), 128.6 and 130.6 (Ph), 136.1 (C-9), 147.3 (C-2), $166.1(\mathrm{C}-6), 177.3\left(\mathrm{CO}_{2} \mathrm{H}\right)$, 206.5 (C=O); HRMS (ESI). Found: $\mathrm{MH}^{+}$, 442.0764. Calc. for $\mathrm{C}_{17} \mathrm{H}_{20} \mathrm{BrN}_{3}: \mathrm{MH}^{+}=442.0761$.

\subsection{Solid-Phase Synthesis with \\ 4-fluoro-3-bromo-1-Nitrobenzene}

\subsubsection{Loading the Piperazine to Merrifield Resin}

General Resin Preparation. The Merrifield resin (1) (5 g) was a suspension in dry DMF $(20 \mathrm{~mL})$ for $6-12 \mathrm{~h}$. The resin had a gel-like appearance double its original volume.

To the resin suspension, a molar excess of free piperazine ( $5 \mathrm{~g})$, pyridine $(2 \mathrm{~mL})$, or $\mathrm{K}_{2} \mathrm{CO}_{3}(3 \mathrm{~g})$, stirred at $80^{\circ} \mathrm{C}$ for $24 \mathrm{~h}$. The cold resin was then filtered and washed with water $(2 \times 20 \mathrm{~mL}), \mathrm{MeOH}(2 \times 20 \mathrm{~mL})$, and $\mathrm{CH}_{2} \mathrm{Cl}_{2}(2 \times 10 \mathrm{~mL})$, then dried in vacuo for a minimum of $24 \mathrm{~h}$ or until a constant weight was achieved $(5.6 \mathrm{~g}) ; v_{\max } / \mathrm{cm}^{-1} 3441(\mathrm{NH})$; (Found: C, 85.1; H, 10.4; N, 2.9\%).

2.9.2. Preparation of 3-bromo-4-(Resin-Supported benzylpiperazine)-1-nitrobenzene (4). 3-Bromo-4-fluoro-1-nitrobenzene (3) (2 g) was stirred in dry DMF $(10 \mathrm{~mL})$, and anhydrous $\mathrm{K}_{2} \mathrm{CO}_{3}(3 \mathrm{~g})$ was added to the suspended piperazineMerrifield resin (2) (3g), and the reaction was continued at $50^{\circ} \mathrm{C}$ for $24 \mathrm{~h}$. The cold resin was filtered, then washed with water $(2 \times 20 \mathrm{~mL}), \mathrm{MeOH}(4 \times 10 \mathrm{~mL})$, and finally with $\mathrm{CH}_{2} \mathrm{Cl}_{2}(2 \times 10 \mathrm{~mL})$. The solid was dried under vacuo for $24 \mathrm{~h}$ or until constant weight $(4.6 \mathrm{~g}) ; \nu_{\max } / \mathrm{cm}^{-1} 1509$ and $1339\left(\mathrm{NO}_{2}\right)$.

2.9.3. Preparation of 3-bromo-4-(4'-Resin-Supported benzylpiperazino)-1-aniline (5). 3-Bromo-4-(4'-resin-supported benzylpiperazine)-1-nitrobenzene 4 ( $2 \mathrm{~g})$ was suspended in dry DMF $(10 \mathrm{~mL})$ for $12 \mathrm{~h}$. An excess of stannous chloride
$(5 \mathrm{~g})$ and $\mathrm{EtOH}(5 \mathrm{~mL})$ was added to the resin. The resulting reaction mixture was stirred at $50^{\circ} \mathrm{C}$ for $8 \mathrm{~h}$. At this time, the resin color changed from yellow to pale yellow. The cold resin was filtered and washed with water $(4 \times 20 \mathrm{~mL})$. The resin was stirred in a solution of $\mathrm{NaHCO}_{3}(20 \% \mathrm{w} / \mathrm{v}, 20 \mathrm{~mL})$, filtered, washed several times with water $(2 \times 20 \mathrm{~mL})$, $\mathrm{NaHCO}_{3}$ solution $(2 \times 20 \mathrm{~mL}), \mathrm{MeOH}(2 \times 20 \mathrm{~mL})$, and finally with $\mathrm{CH}_{2} \mathrm{Cl}_{2}(2 \times 20 \mathrm{~mL})$, and dried to give a yellow resin $(1.8 \mathrm{~g}) ; v_{\max } / \mathrm{cm}^{-1} 3360\left(\mathrm{NH}_{2}\right)$.

2.9.4. Preparation of 3-bromo-4-(4'-Resin-Supported benzylpiperazino)-1-formamide (6). The resin-supported amine 5 $(1 \mathrm{~g})$ was suspended in dry DMF $(10 \mathrm{~mL})$ for $12 \mathrm{~h}$ before the addition of formic acid $(5 \mathrm{~mL})$. The reaction suspension was stirred and heated at $50^{\circ} \mathrm{C}$ for $2 \mathrm{~h}$. the cooled reaction mixture was filtered and washed with water $(4 \times 10 \mathrm{~mL})$ to remove the excess of formic acid. The resin was washed with $\mathrm{NaHCO}_{3}$ solution $(30 \% \mathrm{w} / \mathrm{v}, 20 \mathrm{~mL}), \mathrm{MeOH}(2 \times 10 \mathrm{~mL})$, and finally with $\mathrm{CH}_{2} \mathrm{Cl}_{2}(2 \times 10 \mathrm{~mL})$ to give derivatized resin $6(1.2 \mathrm{~g}) ; \nu_{\max } / \mathrm{cm}^{-1} 3362 \mathrm{~cm}^{-1}(\mathrm{NH}), 1721 \mathrm{~cm}^{-1}(\mathrm{C}=\mathrm{O})$.

2.9.5. Preparation of Resin-Supported 7-bromo-6-piperazino4-oxo-3-quinolone Carboxylic Acid (7). 3-Bromo-4-(4'resin-supported benzylpiperazino)-1-formamide (6) (1 g) was suspended in dry DMF $(10 \mathrm{~mL})$ for $12 \mathrm{~h}$. Phosphorus oxychloride $\left(\mathrm{POCl}_{3}, 5 \mathrm{~mL}\right)$ was added to the suspended resin, and the mixture was stirred for 30 minutes at $25^{\circ} \mathrm{C}$. A solution of methyl malonyl chloride $(1.32 \mathrm{~g}, 9.6 \mathrm{mmoL})$ in $\mathrm{POCl}_{3}(2 \mathrm{~mL})$ was gradually added to the reaction mixture. When the addition was completed, the temperature was gradually raised to $100^{\circ} \mathrm{C}$ for $24 \mathrm{~h}$. After cooling, the reaction mixture was added gradually and carefully to ice $(20 \mathrm{~mL})$ then stirred for a further 20 minutes. The solution was basified using $\mathrm{NaOH}(10 \% \mathrm{w} / \mathrm{v}, 5 \mathrm{~mL})$ and refluxed for a further 30 minutes. The resin was filtered and washed with water $(2 \times 10 \mathrm{~mL})$, $\mathrm{MeOH}(2 \times 10 \mathrm{~mL})$, and finally with $\mathrm{CH}_{2} \mathrm{Cl}_{2}(2 \times 10 \mathrm{~mL})$ and dried in vacuo to constant weight $(1.2 \mathrm{~g}) ; \nu_{\max } / \mathrm{cm}^{-1} 1719 \mathrm{~cm}^{-1}(\mathrm{C}=\mathrm{O})$.

\subsection{Cleavage from the Resin}

\subsubsection{Using the Hydrogenator}

General Method. Resin-supported compound 4-7 (0.3 g) was placed in a hydrogenator vessel and suspended in dry $\mathrm{CH}_{2} \mathrm{Cl}_{2}(5 \mathrm{~mL})$. Pd/C $(0.05 \mathrm{~g})$ was added to the resin suspension and the hydrogenation system was securely sealed. The reaction was carried out under $2 \mathrm{~atm}$ of hydrogen for $24 \mathrm{~h}$. The reaction mixture was filtered, and the resin was washed several times with $\mathrm{MeOH}(4 \times 5 \mathrm{~mL})$; the resulting filtrates combined and the solvent was removed in vacuo to give a black residue $(0.05 \mathrm{~g})$. TLC showed a mixture of several spots, while the ${ }^{1} \mathrm{H}$ NMR spectrum gave a complicated and noncharacterizable spectrum.

\subsubsection{Cleavage by Catalytic Transfer Hydrogenation (Hydrogenolysis)}

General Method. The resin-supported compound 4-7 (0.3 g) was suspended in dry $\mathrm{MeOH}(10 \mathrm{~mL})$. Cyclohexene $(5 \mathrm{~mL})$ 
and $20 \% \mathrm{Pd}(\mathrm{OH})_{2}$ on carbon $(1: 3$ catalyst substrate by weight) was added. The suspended mixture was stirred under dry nitrogen at reflux for $12-48 \mathrm{~h}$; extra cyclohexene $(10 \mathrm{~mL})$ was added in two portions during this reaction time, and the reaction was monitored by TLC $\left(\mathrm{CHCl}_{3}: \mathrm{MeOH}\right.$, $90: 10)$. The reaction mixture was filtered through celite and washed with $\mathrm{MeOH}(3 \times 10 \mathrm{~mL})$. The combined filtrates were collected, dried over $\mathrm{MgSO}_{4}$, and concentrated to give a residue for characterization. None of the compounds 4-7 gave an acceptable cleavage product.

\subsubsection{Cleavage by Formation of a Solid-Supported Tertiary Amine Using Alkyl Halide}

General Method. The compound on resin support 4-7 $(0.3 \mathrm{~g})$ was swollen with a mixture of DMF $(5 \mathrm{~mL})$, and an excess of MeI or EtI (3-4 mL) was added; the mixture was refluxed with slow stirring for $60 \mathrm{~h}$. The resin was crosswashed with $\mathrm{MeOH}(5 \times 10 \mathrm{~mL}), \mathrm{CH}_{2} \mathrm{Cl}_{2}(5 \times 10 \mathrm{~mL})$, and diethyl ether $(10 \mathrm{~mL})$. The dry resin was swollen again with morpholine $(4 \mathrm{~mL})$ and heated at $110^{\circ} \mathrm{C}$ for $20-40 \mathrm{~h}$ and then washed with $\mathrm{MeOH}(2 \times 3 \mathrm{~mL})$, and the filtrate was evaporated. The resulting solid was partitioned between $\mathrm{CH}_{2} \mathrm{Cl}_{2}(5 \mathrm{~mL})$ and aqueous sodium carbonate $(10 \%, 5 \mathrm{~mL})$. Organic layers were collected, dried, and concentrated. None of the expected cleavage products was obtained.

\subsubsection{Cleavage by Formation of a Solid-Supported Tertiary Amine Using $\alpha$-Chloroethyl Chloroformate (ACE-Cl)}

General Method. Compounds on the resin support $(0.5 \mathrm{~g})$ were first suspended in 1,2-dichloropropane $(5 \mathrm{~mL})$, followed by the addition of an excess of $\alpha$-chloroethyl chloroformate $(10 \mathrm{~mL})$. The resulting suspension was stirred at room temperature for $48 \mathrm{~h}$. The resin was filtered through a bed of silica gel, and the filtrate was then concentrated in vacuo until dryness. The residue dissolved in methanol and refluxed for $3 \mathrm{~h}$. The solvent was removed to yield the secondary amines as their $\mathrm{HCl}$ salts.

3-Bromo-4-(4'-resin-supported benzylpiperazine)-1nitrobenzene (4) (0.5 g) was swollen in 1,2-dichloropropane $(5 \mathrm{~mL})$ for $12 \mathrm{~h}$, and ACE-Cl $(10 \mathrm{~mL})$ was then added. The resulting suspension was stirred at room temperature for $48 \mathrm{~h}$ and then treated as for the general method. The resulting black residue $(0.3 \mathrm{~g})$ was refluxed in ethanol for $3 \mathrm{~h}$, and reaction was monitored by TLC. $\left(\mathrm{CHCl}_{3}\right.$ :petroleum ether (40-60), 60:40). The TLC showed a complicated mixture of spots; the major product at $R_{f}=0.34$ was separated by preparative thin layer chromatography to give 3-bromo-4-ethoxy-1-nitrobenzene.

2.11. Preparation of $\mathrm{N}$-(2-fluoro-5-nitrophenyl) piperazine (13) [15] the N,N-bis-(2-chloroethyl)ammonium chloride is very toxic and must be handled with care only in fuming hood. A mixture of 2-fluoro-5-nitroaniline (1 g, $6.4 \mathrm{mmoL}$ ) and $\mathrm{N}, \mathrm{N}$-bis-(2-chloroethyl)ammonium chloride $(1.3 \mathrm{~g}, 7.0 \mathrm{mmoL})$ in diethylene glycol monomethyl ether $(1 \mathrm{~mL})$ was heated under dry nitrogen at $150 \circ \mathrm{C}$ for $24 \mathrm{~h}$. The reaction was monitored by TLC (ethyl acetate: $\mathrm{CHCl}_{3}, 80: 20$ ), product $R_{f}=0.42$, the dark solid of $\mathrm{N}$-(2-fluoro-5-nitrophenyl) piperazine $13(0.87 \mathrm{~g}, 60 \%)$; $\mathrm{mp} 216-217^{\circ} \mathrm{C} ; v_{\max } / \mathrm{cm}^{-1} 3386(\mathrm{NH}), 1522$ and $1346\left(\mathrm{NO}_{2}\right)$; $\delta_{\mathrm{H}}\left(300 \mathrm{MHz} ; \mathrm{DMSO}-d_{6}\right)[16] 3.26\left(4 \mathrm{H}, \mathrm{m}, \mathrm{CH}_{2}-3^{\prime}\right.$ and $\left.\mathrm{CH}_{2}-5^{\prime}\right), 3.40\left(4 \mathrm{H}, \mathrm{m}, \mathrm{CH}_{2}-2^{\prime}\right.$ and $\left.\mathrm{CH}_{2}-6^{\prime}\right), 7.49(1 \mathrm{H}, \mathrm{dd}$, $J=9.0 \mathrm{~Hz}$ and $12 \mathrm{~Hz}, \mathrm{H}-3), 7.85(1 \mathrm{H}, \mathrm{dd}, J=3$ and $9 \mathrm{~Hz}$, $\mathrm{H}-6), 7.94(1 \mathrm{H}, \mathrm{m}, \mathrm{H}-4), 9.59(1 \mathrm{H}, \mathrm{br} \mathrm{s}, \mathrm{NH}) ; \delta_{\mathrm{C}}(75 \mathrm{~Hz}$; DMSO- $\left.d_{6}\right) 43.0\left(\mathrm{C}-3^{\prime}\right.$ and C-5', $47.0\left(\mathrm{C}-2^{\prime}\right.$ and C- $\left.6^{\prime}\right), 115.2$ $(\mathrm{d}, J=5.3 \mathrm{~Hz}, \mathrm{C}-6), 117.8(\mathrm{~d}, J=24 \mathrm{~Hz}, \mathrm{C}-3), 119.2(\mathrm{~d}$, $J=10.5 \mathrm{~Hz}, \mathrm{C}-4), 139.9(\mathrm{~d}, J=9.8 \mathrm{~Hz}, \mathrm{C}-1), 144.9$ (C-5), $158.8(\mathrm{~d}, J=257 \mathrm{~Hz}, \mathrm{C}-2)$.

\subsection{Solid Phase Reaction Using p-nitrophenyl Carbonate Wang Resin 14}

2.12.1. Reactions of N-(2-fluoro-5-nitrophenyl) piperazine with p-nitrophenyl Carbonate Wang Resin (14). p-Nitrophenyl carbonate Wang resin $\mathbf{1 4}(1 \mathrm{~g}$, loading: 0.60 $1.20 \mathrm{mmoL} / \mathrm{g}$ resin) was first suspended in dry DMF $(5 \mathrm{~mL})$ for $5 \mathrm{~h}$, and $N$-(2-fluoro-5-nitrophenyl) piperazine $\mathbf{1 3}(1.6 \mathrm{~g}$, $7.1 \mathrm{mmoL})$, and dry pyridine $(2 \mathrm{~mL})$ were then added to resin. The resulting suspension was then stirred and heated to $35^{\circ} \mathrm{C}$ for $24 \mathrm{~h}$. After cooling to room temperature, the resin was filtered and washed with water $(2 \times 10 \mathrm{~mL})$, methanol $(3 \times 10 \mathrm{~mL})$ and $\mathrm{CH}_{2} \mathrm{Cl}_{2}(3 \times 10 \mathrm{~mL})$. The resin was dried under vacuo to give a brown resin $(2.3 \mathrm{~g})$. The residual product was verified by the complete disappearance of the characteristic carbonate resin band at $1760 \mathrm{~cm}^{-1} ; \nu_{\max } / \mathrm{cm}^{-1}$ 1555 and $1316\left(\mathrm{NO}_{2}\right), 1669(\mathrm{C}=\mathrm{O})$.

2.12.2. Resin Cleavage [17]. The nitrocarbonate resin $\mathbf{1 5}$ $(0.2 \mathrm{~g})$ was suspended in trifluoroacetic acid $(2 \mathrm{~mL})$, dichloromethane $(2 \mathrm{~mL})$ and stirred at room temperature for $3 \mathrm{~h}$. The cleavage reaction was monitored by TLC $\left[\left(\mathrm{CH}_{2} \mathrm{Cl}_{2}: \mathrm{MeOH}, 80: 20\right)\right.$ on the solution, product $R_{f}=$ $0.42]$. The resin was filtered and washed with $\mathrm{CH}_{2} \mathrm{Cl}_{2}(4$ $\times 20 \mathrm{~mL}$ ), and the filtrate was collected and then extracted with $\mathrm{NaHCO}_{3}(10 \%, 4 \times 20 \mathrm{~mL})$. The $\mathrm{CH}_{2} \mathrm{Cl}_{2}$ layers were collected, washed with brine $(2 \times 20 \mathrm{~mL})$, and dried over $\mathrm{MgSO}_{4}$. The solvent was removed under vacuo to give a yellow crystal of $13(0.1 \mathrm{~g})$.

2.12.3. Reduction of N-(2-fluoro-5-nitrophenyl)piperazinecarbonate Wang Resin (15). N-(2-fluoro-5-nitrophenyl)piperazine-carbonate Wang resin $15(0.3 \mathrm{~g})$ was suspended in anhydrous DMF $(5 \mathrm{~mL})$ and $\mathrm{Et}_{3} \mathrm{~N}(2 \mathrm{~mL})$. Anhydrous stannous chloride $(1 \mathrm{~g})$ and absolute ethanol $(5 \mathrm{~mL})$ were then added to the resin, and the reaction mixture was stirred at room temperature for $24 \mathrm{~h}$ (the color changed from deep yellow to light grey). The resin was filtered washed with methanol $(20 \mathrm{~mL})$, water $(3 \times 20 \mathrm{~mL})$, methanol $(3 \times$ $10 \mathrm{~mL})$, and $\mathrm{CH}_{2} \mathrm{Cl}_{2}(3 \times 10 \mathrm{~mL})$. The resin was dried to give the resin supported amine $(0.34 \mathrm{~g}) ; v_{\max } / \mathrm{cm}^{-1} 3401$ and 3385 $\left(\mathrm{NH}_{2}\right), 1672(\mathrm{OC}=\mathrm{O})$.

2.12.4. Reaction of N-(2-fluoro-5-aminophenyl) piperazinecarbonate Wang Resin 16 with Ethyl Formate. N-(2Fluoroaniline) piperazine-carbonate Wang resin $(0.3 \mathrm{~g})$ was 
suspended in dry DMF $(5 \mathrm{~mL})$ (the resin doubled in volume), under a positive flow of dry nitrogen, and ethyl formate was added $(5 \mathrm{~mL})$. The resulting mixture was stirred at $30^{\circ} \mathrm{C}$ for $24 \mathrm{~h}$ and, after cooling to room temperature, the resin was filtered off. TLC of the filtrate showed a spot at $R_{f}=$ $0.32\left(\mathrm{CHCl}_{3}: \mathrm{MeOH}, 96: 4\right)$. The resin was washed with water $(3 \times 10 \mathrm{~mL})$, methanol $(3 \times 10 \mathrm{~mL})$, and $\mathrm{CH}_{2} \mathrm{Cl}_{2}(2$ $\times 10 \mathrm{~mL})$ to give, after drying, the corresponding formamide resin $16(0.21 \mathrm{~g}) ; \nu_{\max } / \mathrm{cm}^{-1} 3406(\mathrm{NH})$ and $1685(N-\mathrm{C}=\mathrm{O})$, $1662(\mathrm{OC}=\mathrm{O})$.

2.13. Preparation of 1-(benzoylpiperazinyl)-2-fluoro-5-nitrobenzene (19). N-(2-Fluoro-5-nitrophenyl)piperazine (13) (3 g, $13.3 \mathrm{mmoL})$ was dissolved in $\mathrm{CHCl}_{3}(20 \mathrm{~mL}), \mathrm{K}_{2} \mathrm{CO}_{3}$ ( $5.5 \mathrm{~g}, 40 \mathrm{mml}$ ) and $\mathrm{H}_{2} \mathrm{O}(20 \mathrm{~mL})$ were added to the above solution, and benzoyl chloride $(3.73 \mathrm{~g}, 26.6 \mathrm{mmoL})$ was added gradually over 20 minutes. The reaction continued at $35^{\circ} \mathrm{C}$ for 1 hour. The organic layer was separated, washed with water $(3 \times 20 \mathrm{~mL})$ and brine $(30 \mathrm{~mL})$, dried over $\mathrm{MgSO}_{4}$, and concentrated in vacuo to give a yellow shiny crystal of 19 ( $4 \mathrm{~g}, 92 \%)$; mp $108-109^{\circ} \mathrm{C}$; (Calc. for $\mathrm{C}_{18} \mathrm{H}_{18} \mathrm{FN}_{3} \mathrm{O}_{2}$ : C, 66.0; $\mathrm{H}, 5.5 ; \mathrm{N}, 12.8$. Found: C, 66.1; $\mathrm{H}, 5.5 ; \mathrm{N}, 12.7) ; v_{\max } / \mathrm{cm}^{-1} 1694(\mathrm{CO}-\mathrm{N}), 1508\left(\mathrm{NO}_{2}\right)$, $1347\left(\mathrm{NO}_{2}\right) ; \delta_{\mathrm{H}}\left(300 \mathrm{MHz} ; \mathrm{DMSO}-d_{6}\right) 2.94\left(4 \mathrm{H}, \mathrm{s}, \mathrm{CH} 22^{\prime}\right.$, $\left.\mathrm{CH} 2-6^{\prime}\right), 3.49$ (2H, s, CH2-3'), 3.71 (2H, s, CH2-5' $), 7.46$ $(6 \mathrm{H}, \mathrm{m}, \mathrm{Ph}+\mathrm{H}-3), 7.81(1 \mathrm{H}, \mathrm{dd}, J=3$ and $7.5 \mathrm{~Hz}, \mathrm{H}-6)$, $7.92(1 \mathrm{H}, \mathrm{m}, \mathrm{H}-4) ; \delta_{\mathrm{C}}\left(75 \mathrm{MHz} ; \mathrm{DMSO}-d_{6}\right) 41.3\left(\mathrm{C}-5^{\prime}\right)$, $46.9\left(\mathrm{C}-3^{\prime}\right), 49.6\left(\mathrm{C}-2^{\prime}\right.$ and C-6 $), 115.2(\mathrm{~d}, J=5.2 \mathrm{~Hz}, \mathrm{C}-6)$, $117.7(\mathrm{~d}, J=23.0 \mathrm{~Hz}, \mathrm{C}-3), 118.8$ (d, $J=9.5 \mathrm{~Hz}, \mathrm{C}-4), 128.9$ (Ph), 135.9 (C-8), 140.7 (d, J = $10 \mathrm{~Hz}, \mathrm{C}-1), 144.9$ (C-5), $158.9(\mathrm{~d}, J=254 \mathrm{~Hz}, \mathrm{C}-2), 169.6(\mathrm{C}=\mathrm{O})$.

2.14. Preparation of 1-(benzoylpiperazinyl)-2-fluoro-aniline (20) [14]. 1-(benzoylpiperazinyl)-2-fluoroaniline (20) (2.14 g, $78 \%$ ); mp 89-90 ${ }^{\circ}$; (Calc. for $\mathrm{C}_{17} \mathrm{H}_{18} \mathrm{FN}_{3} \mathrm{O}$ : C, 68.2; H, 6.1; $\mathrm{N}, 14.0$. Found: $\mathrm{C}, 68.2 ; \mathrm{H}, 6.05 ; \mathrm{N}, 14.0) ; \nu_{\max } / \mathrm{cm}^{-1} 3450$ and $3350\left(\mathrm{NH}_{2}\right), 1724(\mathrm{CO}-\mathrm{N}) ; \delta_{\mathrm{H}}\left(300 \mathrm{MHz} ; \mathrm{DMSO}-d_{6}\right)$ $2.94\left(4 \mathrm{H}, \mathrm{s}, \mathrm{CH}_{2}-2^{\prime}\right.$ and $\left.\mathrm{CH}_{2}-6^{\prime}\right), 3.48\left(2 \mathrm{H}, \mathrm{s}, \mathrm{CH}_{2}-3^{\prime}\right), 3.73$ $\left(2 \mathrm{H}, \mathrm{s}, \mathrm{CH}_{2}-5^{\prime}\right), 4.84\left(2 \mathrm{H}\right.$, br s, $\left.\mathrm{NH}_{2}\right), 6.13(1 \mathrm{H}, \mathrm{m}, \mathrm{H}-$ 4), $6.25(1 \mathrm{H}, \mathrm{dd}, J=2.4$ and $7.5 \mathrm{~Hz}, \mathrm{H}-6), 6.77(1 \mathrm{H}, \mathrm{dd}$, $J=8.7$ and $12.6 \mathrm{~Hz}, \mathrm{H}-3), 7.45(5 \mathrm{H}, \mathrm{m}, \mathrm{Ph}) ; \delta_{\mathrm{C}}(75 \mathrm{MHz}$; DMSO- $\left.d_{6}\right) 50.17\left(2 \mathrm{CH}_{2}\right), 50.22\left(2 \mathrm{CH}_{2}\right), 105.5(\mathrm{C}-6), 107.6$ (d, $J=7.1 \mathrm{~Hz}, \mathrm{C}-4), 116.3$ (d, $J=21.2 \mathrm{~Hz}, \mathrm{C}-3), 128.9(\mathrm{Ph})$, $140.0(\mathrm{~d}, J=9.5 \mathrm{~Hz}, \mathrm{C}-1), 145.9(\mathrm{C}-5), 147.7$ (d, $J=230 \mathrm{~Hz}$, C-2), 169.5 ( $\mathrm{C}=\mathrm{O})$.

2.15. Preparation of 1-(benzoylpiperazinyl)-2-fluoro-formanilide (21). Formic acid (5 mL) was added to 1-(benzoylpiperazin-1-yl)-2-fluoroaniline (20) (1 g, $3.34 \mathrm{mmoL})$; the resulting solution was heated at $70^{\circ} \mathrm{C}$ for $2 \mathrm{~h}$. The cooled reaction mixture was added to cooled water $(100 \mathrm{~mL})$, extracted with $\mathrm{CHCl}_{3}(4 \times 20 \mathrm{~mL})$ and brine $(30 \mathrm{~mL})$, and dried over $\mathrm{MgSO}_{4}$. The resulting white solid was purified by column chromatography $\left(\mathrm{CHCl}_{3}: \mathrm{MeOH}, 97: 3\right)$ to give white crystals of $21(0.62 \mathrm{~g}, 56 \%)$; mp $189-191^{\circ} \mathrm{C}$; (Calc. for $\mathrm{C}_{18} \mathrm{H}_{18} \mathrm{FN}_{3} \mathrm{O}_{2}$ : C, 66.0; H, 5.5; N, 12.8. Found: C, 66.0; H, $5.5 ; \mathrm{N}, 12.8) ; v_{\max } / \mathrm{cm}^{-1} 3080(\mathrm{NH}) 1684(\mathrm{NH}-\mathrm{CHO}), 1620$ $(\mathrm{CO}-\mathrm{Ph}) ; \delta_{\mathrm{H}}\left(300 \mathrm{MHz}\right.$; DMSO- $\left.d_{6}\right) 3.02\left(4 \mathrm{H}, \mathrm{s}, \mathrm{H}-2^{\prime}, \mathrm{H}-6^{\prime}\right)$, $3.55\left(2 \mathrm{H}, \mathrm{s}, \mathrm{H}-3^{\prime}\right), 3.74\left(2 \mathrm{H}, \mathrm{s}, \mathrm{H}-5^{\prime}\right), 7.11(1 \mathrm{H}, \mathrm{dd}, J=8.7$ and $J=12.0 \mathrm{~Hz}, \mathrm{H}-3), 7.19(1 \mathrm{H}$, ddd, $J=8.7,2.7$ and $1.5 \mathrm{~Hz}, \mathrm{H}-4), 7.35(1 \mathrm{H}, \mathrm{dd}, J=2.7$ and $J=5.4 \mathrm{~Hz}, \mathrm{H}-$ 6), $7.46(5 \mathrm{H}, \mathrm{m}, \mathrm{CO}-\mathrm{Ph}), 8.25(1 \mathrm{H}, \mathrm{d}, J=1.8 \mathrm{~Hz}, \mathrm{CHO})$, $10.12\left(1 \mathrm{H}\right.$, br s, NH); $\delta_{\mathrm{C}}\left(75 \mathrm{MHz}\right.$; DMSO- $\left.d_{6}\right) 50.2$ and 50.22 (piperazine-C), 111.1 (C-6), 113.7 (d, $J=7.5 \mathrm{~Hz}, \mathrm{C}-4), 116.5$ $(\mathrm{d}, J=21.0 \mathrm{~Hz}, \mathrm{C}-3), 128.9(\mathrm{Ph}), 136.3(\mathrm{C}-5), 140.0(\mathrm{~d}$, $J=9.0 \mathrm{~Hz}, \mathrm{C}-1), 153.1$ (d, $J=240 \mathrm{~Hz}, \mathrm{C}-2), 159.9(\mathrm{CHO})$, $169.6(\mathrm{C}=\mathrm{O})$.

2.16. Vilsmeier Reaction of 3-nitro-4-fluoroformanilide. Preparation of $N, N^{\prime}$-Bis-(4-fluoro-3-nitrophenyl)oxala-mide 23.

Under anhydrous conditions, 3-chloro-4-fluoroformanilide $(2 \mathrm{~g}, 10.86 \mathrm{mmoL})$ was dissolved in dry $\mathrm{CHCl}_{3}$ $(20 \mathrm{~mL})$, then $(\mathrm{COCl})_{2}(2 \mathrm{~mL})$ was added gradually over 30 minutes, (a vigorous reaction was observed). The resulting reaction mixture was heated to $40^{\circ} \mathrm{C}$ for 30 minutes. The reaction flask was removed from the oil bath; methyl malonyl chloride $(1.78 \mathrm{~g}, 13.03 \mathrm{mmoL})$ in $\mathrm{CHCl}_{3}(2 \mathrm{~mL})$ was added gradually to the Vilsmeier reagent over $30 \mathrm{~min}$. The reaction was continued at $40^{\circ} \mathrm{C}$ for $3 \mathrm{~h}$ until the TLC of the reaction showed a complete consumption of the starting formanilide, with the formation of a new product above the starting compound, $\left[\left(\mathrm{CHCl}_{3}: \mathrm{MeOH}, 95: 5\right) R_{f}=0.56\right]$. The reaction mixture was concentrated in vacuo, followed by the addition of cooled water $(20 \mathrm{~mL})$, and stirred for 30 minutes. The resulting yellow solid was collected by filtration, washed with water, and recrystallized from $\mathrm{CHCl}_{3}$ to give yellow crystals of $N, N^{\prime}$-Bis-(4-fluoro-3-nitrophenyl)oxalamide (23) (0.62 g, $16 \%$ ); mp $109-111^{\circ} \mathrm{C}$; (Calc. for $\mathrm{C}_{14} \mathrm{H}_{8} \mathrm{~F}_{2} \mathrm{~N}_{4} \mathrm{O}_{6}$ : C, 45.9; $\mathrm{H}$, $2.2 ; \mathrm{N}, 15.3$. Found: C, 45.9; H, 2.2; N, 15.3); $v_{\max } / \mathrm{cm}^{-1} 3275$ $(\mathrm{NH}), 1673(\mathrm{NCO}) ;{ }^{1} \mathrm{H}$ NMR $\delta_{\mathrm{H}}\left(300 \mathrm{MHz}\right.$; DMSO-d $\left.d_{6}\right) 7.64$ $\left(2 \mathrm{H}, \mathrm{t}, J=9.0 \mathrm{~Hz}, \mathrm{H}-5\right.$ and $\left.\mathrm{H}-5^{\prime}\right), 8.23(2 \mathrm{H}, \mathrm{m}, \mathrm{H}-6$ and $\mathrm{H}-$ $\left.6^{\prime}\right), 8.80\left(2 \mathrm{H}, \mathrm{dd}, J=0.8\right.$ and $1.5 \mathrm{~Hz}, \mathrm{H}-2$ and $\left.\mathrm{H}-2^{\prime}\right), 11.40$ $(2 \mathrm{H}, \mathrm{s}, 2 \mathrm{NH}) ; \delta_{\mathrm{C}}\left(75 \mathrm{MHz} ; \mathrm{CDCl}_{3}\right) 120.1\left(\mathrm{C}-2\right.$ and $\left.\mathrm{C}-2^{\prime}\right)$, $121.7\left(\mathrm{~d}, J=22.5 \mathrm{~Hz}, \mathrm{C}-5\right.$ and $\left.\mathrm{C}-5^{\prime}\right), 130.9(\mathrm{~d}, J=7.5 \mathrm{~Hz}$, C-6 and C-6' $6^{\prime}$, 137.2 (C-1 and C-1 ${ }^{\prime}$ ), 139.1 (d, J = 7.5 Hz, C-3 and C-3' $3^{\prime}, 154.1$ (d, $J=262.5 \mathrm{~Hz}, \mathrm{C}-4$ and C-4' $), 161.2$ $(\mathrm{C}=\mathrm{O})$.

\subsection{Vilsmeier Reaction on 3-chloro-4-fluoroformanilide and} Preparation of $N, N^{\prime}$-Bis-(3-chloro-4-fluorophenyl)malonamide (24). Under anhydrous conditions, 3-chloro-4fluoroformanilide $(2 \mathrm{~g}, 12.98 \mathrm{mmoL})$ was dissolved in $\mathrm{CHCl}_{3}(20 \mathrm{~mL})$. Oxalyl chloride $(2 \mathrm{~mL})$ was added gradually over $30 \mathrm{~min}$. (vigorous reaction). The resulting reaction mixture was heated to $40^{\circ} \mathrm{C}$ for 30 minutes. Methyl malonyl chloride $(2.13 \mathrm{~g}, 15.57 \mathrm{mmoL})$ was added gradually to the cooled reaction mixture over 30 minutes. When addition was complete, the reaction was continued at $40^{\circ} \mathrm{C}$ for $3 \mathrm{~h}$ until TLC showed a complete consumption of the starting formanilide with formation of a new product above the starting compound [ $\left.\left(\mathrm{CHCl}_{3}: \mathrm{MeOH}, 97: 3\right) R_{f}=0.53\right]$. The reaction mixture was concentrated in vacuo; cold water $(20 \mathrm{~mL})$ was then added and the mixture stirred for 30 minutes. The resulting yellow solid was collected by filtration, washed with water, and purified by column chromatography $\left(\mathrm{CHCl}_{3}\right)$. The solid was recrystallized from 
TABLE 1: The preliminary screening of antimicrobial activity of the new synthesized compounds.

\begin{tabular}{|c|c|c|c|c|c|c|}
\hline \multirow{3}{*}{ Compounds/DMF $50 \mu \mathrm{g} / \mathrm{ml}$ disk } & \multicolumn{6}{|c|}{ Microorganisms/Inhibition zone (mm) } \\
\hline & \multicolumn{2}{|c|}{ Gram +ve bacteria ${ }^{a}$} & \multicolumn{2}{|c|}{ Gram - ve bacteriab $^{\mathrm{b}}$} & \multicolumn{2}{|c|}{ Fungi $^{\mathrm{c}}$} \\
\hline & B.S. & $S . A$ & E.C. & K.P. & C.A. & A.F. \\
\hline 19 & 9 & 8 & 8 & 10 & 10 & 6 \\
\hline 20 & 18 & 16 & 15 & 14 & 10 & 6 \\
\hline 21 & 16 & 16 & 14 & 14 & 8 & 6 \\
\hline 9 & 8 & 8 & 7 & 11 & 9 & 6 \\
\hline 11 & 13 & 11 & 12 & 13 & 9 & 6 \\
\hline 23 & 15 & 14 & 15 & 13 & 10 & 6 \\
\hline 12 & 20 & 19 & 18 & 17 & 10 & 10 \\
\hline Ny. & 6 & 6 & 6 & 10 & 10 & 32 \\
\hline $\mathrm{Na}$. & 32 & 30 & 30 & 22 & 6 & 6 \\
\hline
\end{tabular}

Ny: nystatin, manufactured by Pasteur Lab., Egypt. NS 100 units (100 $\mu \mathrm{g} /$ disk).

Na: nalidixic acid, $30 \mu \mathrm{g} /$ disk, Bioanalize, Egypt.

${ }^{\mathrm{a}}$ Bacillus Subtilis (B.S.) and Stphylacoccus Aureus (S.A.); ${ }^{\mathrm{b}}$ Escherichia Coli (E.C.) and Klebsiella Pneumonia (K.P.); ${ }^{\mathrm{c}}$ Candida Albicans (C.A.) and Aspergillus Funigates (A.F.).

TABLE 2: MIC of the active biological compounds towards bacteria.

\begin{tabular}{|c|c|c|c|c|c|c|c|c|c|c|c|c|}
\hline \multirow{3}{*}{ Compd. No. } & \multicolumn{12}{|c|}{ Inhibition Zones $(\mu \mathrm{g} / \mathrm{mm})$} \\
\hline & \multicolumn{3}{|c|}{ B.S. } & \multicolumn{3}{|c|}{ S.A. } & \multicolumn{3}{|c|}{ E.C. } & \multicolumn{3}{|c|}{ K.P. } \\
\hline & 50 & 40 & 30 & 50 & 40 & 30 & 50 & 40 & 30 & 50 & 40 & 30 \\
\hline 20 & 18 & 12 & 6 & 16 & 14 & 10 & 15 & 12 & 10 & 14 & 12 & 8 \\
\hline 21 & 16 & 14 & 6 & 16 & 12 & 10 & 14 & 13 & 10 & 14 & 11 & 9 \\
\hline 11 & 13 & 10 & 6 & 11 & 10 & 10 & 12 & 10 & 6 & 13 & 11 & 10 \\
\hline 23 & 15 & 12 & 6 & 14 & 12 & 10 & 15 & 12 & 6 & 13 & 11 & 9 \\
\hline 12 & 20 & 18 & 15 & 19 & 16 & 10 & 18 & 16 & 12 & 17 & 14 & 12 \\
\hline
\end{tabular}

TABLE 3: Preliminary screening using UV $(\lambda 366 \mathrm{~nm})$ light, conc. $50 \mu \mathrm{g} /$ disk.

\begin{tabular}{|c|c|c|c|c|c|c|}
\hline \multirow{3}{*}{ Compd. No. } & \multicolumn{6}{|c|}{ Microorganisms (inhibition zones in mm) } \\
\hline & \multicolumn{2}{|c|}{ +ve bacteria } & \multicolumn{2}{|c|}{ - ve bacteria } & \multicolumn{2}{|c|}{ Fungi } \\
\hline & B.S. & S.A. & E.C & K.P. & C.A. & A.F. \\
\hline 20 & 18 & 16 & 15 & 14 & No change & No change \\
\hline 21 & 18 & 17 & 16 & 18 & No change & No change \\
\hline 11 & 14 & 14 & 12 & 14 & No change & No change \\
\hline 23 & 17 & 16 & 17 & 16 & No change & No change \\
\hline 12 & 24 & 21 & 21 & 21 & No change & No change \\
\hline
\end{tabular}

TABLE 4: Various physicochemical properties of highly bioactive compounds.

\begin{tabular}{|c|c|c|c|c|c|c|c|c|}
\hline \multirow{2}{*}{ Compd. No. } & \multicolumn{4}{|c|}{ MIC at $30 \mu \mathrm{g} / \mathrm{disc}$} & \multirow{2}{*}{ Mol. Mass } & \multicolumn{2}{|c|}{ Melting point } & \multirow{2}{*}{ Solubility in water $\left(20^{\circ} \mathrm{C}\right), \mu \mathrm{g} / \mathrm{L}$} \\
\hline & B.S & S.A & E.C & K.P & & $\mathrm{CHCl}_{3}{ }^{\mathrm{a}}$ & Cyclo-Hexane ${ }^{\mathrm{b}}$ & \\
\hline 20 & 6 & 10 & 10 & 8 & 299 & 90 & 87 & 200 \\
\hline 21 & 6 & 10 & 10 & 9 & 327 & 191 & 186 & 300 \\
\hline 11 & 6 & 10 & 6 & 10 & 374 & 74 & 70 & 90 \\
\hline 23 & 6 & 10 & 6 & 9 & 366 & 111 & 107 & 350 \\
\hline 12 & 15 & 10 & 12 & 12 & 442 & 285 & - & 400 \\
\hline $\mathrm{Ny}$ & 6 & 6 & 6 & 6 & - & - & - & - \\
\hline $\mathrm{Na}$ & 32 & 30 & 30 & 32 & - & - & - & - \\
\hline
\end{tabular}

${ }^{a}$ Crystals cyclisation from $\mathrm{CHCl}_{3} ;{ }^{\mathrm{b}}$ Crystals cyclisation from cyclohexane; ${ }^{\mathrm{c}}$ hydrolysis characteristics at $\mathrm{pH} 5.7$ and 9 and at $24^{\circ} \mathrm{C}$. The tested compounds have a very low rate of hydrolysis, which is considered stable in suspension concentrations under normal condition. 


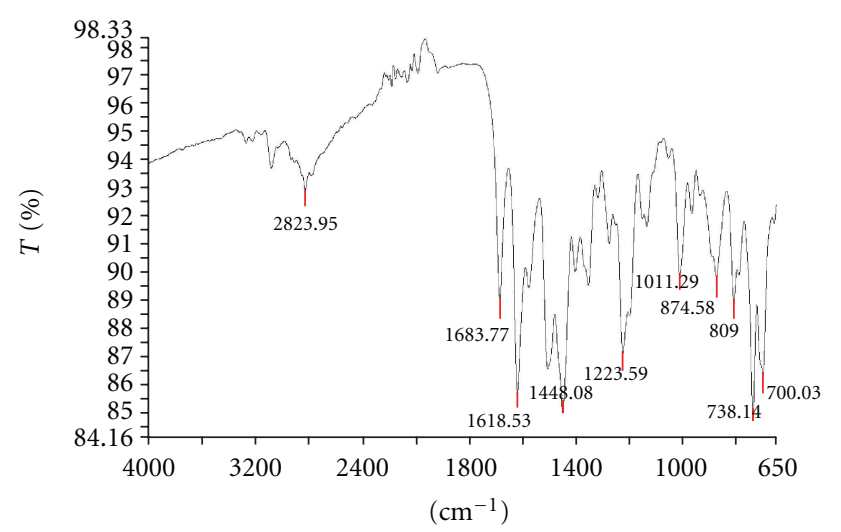

(a) Solid state

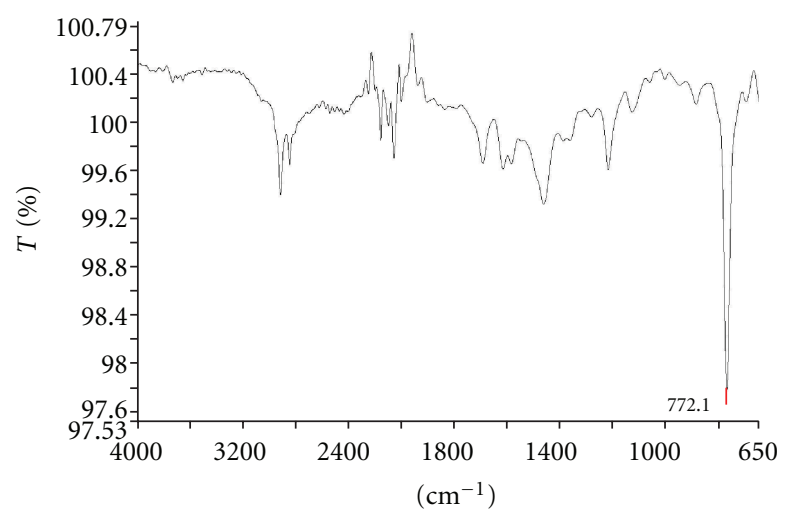

(b) Solution state

FIgURE 1: FT-IR spectrum of 12 in (a) solid and (b) solution states for compound 12.

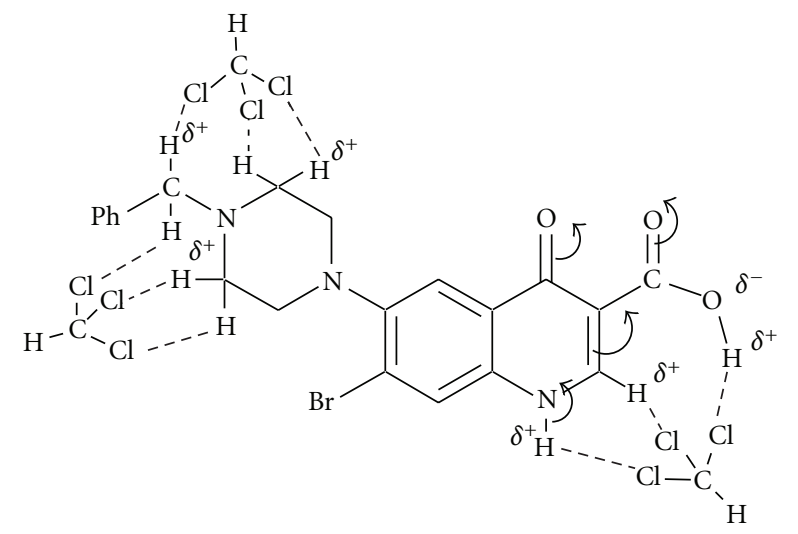

FIgURE 2: The interaction between compound 12 with $\mathrm{CHCl}_{3}$.

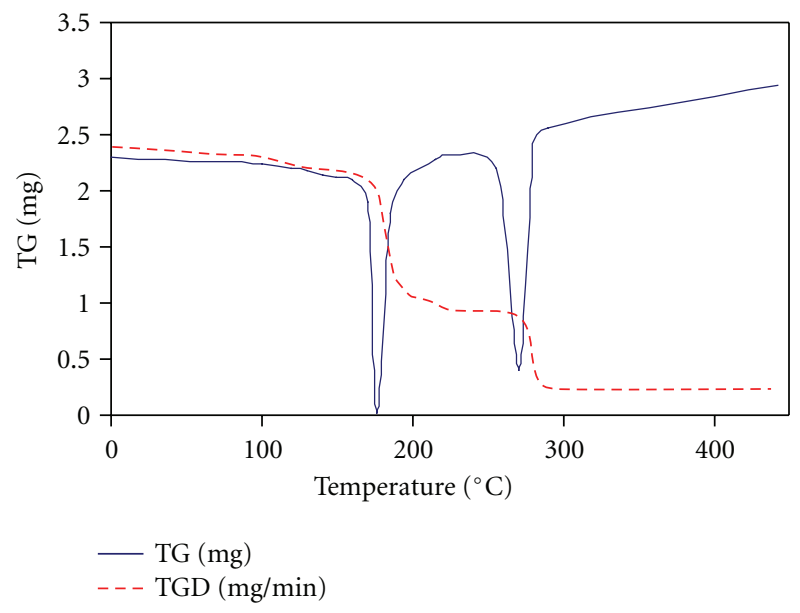

FIGURe 3: TG and TGD for compound 12.

$\mathrm{CHCl}_{3}$ to give shiny needle-like crystals of compound $24 \mathrm{~N}$, $N^{\prime}$-Bis-(3-chloro-4-fluorophenyl)malon-amide

$(0.72 \mathrm{~g}$, $18 \%$ ); mp 201-202 ${ }^{\circ} \mathrm{C}$; (Calc. for $\mathrm{C}_{15} \mathrm{H}_{10} \mathrm{Cl}_{2} \mathrm{~F}_{2} \mathrm{~N}_{2} \mathrm{O}_{2}$ : C, 50.2; $\mathrm{H}, 2.8 ; \mathrm{N}, 7.8$. Found: C, $50.2 ; \mathrm{H}, 2.8 ; \mathrm{N}, 7.8) ; \nu_{\max } / \mathrm{cm}^{-1}$

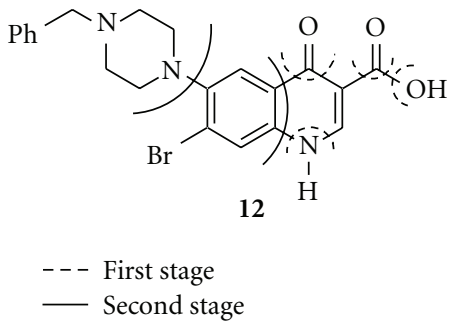

Figure 4: Suggested decomposition stages for compound 12.

3281 (br, NH), $1677(\mathrm{C}=\mathrm{O}), 1497(\mathrm{NH}), 811(\mathrm{Cl}-\mathrm{C}=\mathrm{O})$; $\delta_{\mathrm{H}}\left(300 \mathrm{MHz}\right.$; DMSO- $\left.d_{6}\right) 7.38(2 \mathrm{H}, \mathrm{t}, J=9.0 \mathrm{~Hz}, \mathrm{H}-5$ and $\left.\mathrm{H}-5^{\prime}\right), 7.48\left(2 \mathrm{H}\right.$, ddd, $J=2.4,4.5$ and $9.0 \mathrm{~Hz}, \mathrm{H}-6$ and $\left.\mathrm{H}-6^{\prime}\right)$, $7.93\left(2 \mathrm{H}, \mathrm{dd}, J=2.4\right.$ and $2.7 \mathrm{~Hz}, \mathrm{H}-2$ and $\left.\mathrm{H}-2^{\prime}\right), 10.39(2 \mathrm{H}$, s, $2 \mathrm{NH}) ; \delta_{\mathrm{C}}\left(75 \mathrm{MHz} ; \mathrm{DMSO}-d_{6}\right) 46.3\left(\mathrm{CH}_{2}\right), 117.5(\mathrm{~d}$, $J=21.7 \mathrm{~Hz}, \mathrm{C}-5$ and $\left.\mathrm{C}-5^{\prime}\right), 119.7(\mathrm{~d}, J=18 \mathrm{~Hz}, \mathrm{C}-3$ and C-3'), $119.9\left(\mathrm{~d}, J=7.5 \mathrm{~Hz}, \mathrm{C}-6\right.$ and C-6 $\left.{ }^{\prime}\right), 121.0(\mathrm{C}-2$ and C-2' $), 136.6\left(\mathrm{C}-1\right.$ and $\left.\mathrm{C}-1^{\prime}\right), 153.7(\mathrm{~d}, J=240 \mathrm{~Hz}, \mathrm{C}-4$ and C-4'), $165.9(\mathrm{C}=\mathrm{O})$.

2.18. Physicochemical Studies. The physicochemical studies include the lipophilicity, Fourier transforms infrared spectroscopy, and the thermal stability of highly bioactive compounds. The thermal behaviors for the bioactive compound 12 was investigated by thermogravimetric technique and indicated by the TGD peaks at 177 and $270^{\circ} \mathrm{C}$ (Figures 3 and 4 ). The highly bioactive pure tested compounds were also determined like melting point, water solubility and $\mathrm{pKa}$ values.

2.19. Antimicrobial Assay. Some synthesized compounds, 19, $20,21,9,11,23$, and 12 , were evaluated for their antimicrobial effects by Agar diffusion disk method [18] using Nutrient Agar, MacConkey Agar, and Sabouraud Dextrose Agar. The potentialities of these compounds were estimated against some important and representative microbes like Gram + ve: Bacillus Subtilis (B.S.); Staphylococcus Aureus (S.A.), Gram -ve: Escherichia Coli (E.C.); Klebsiella Pneumonia (K.P.), and 


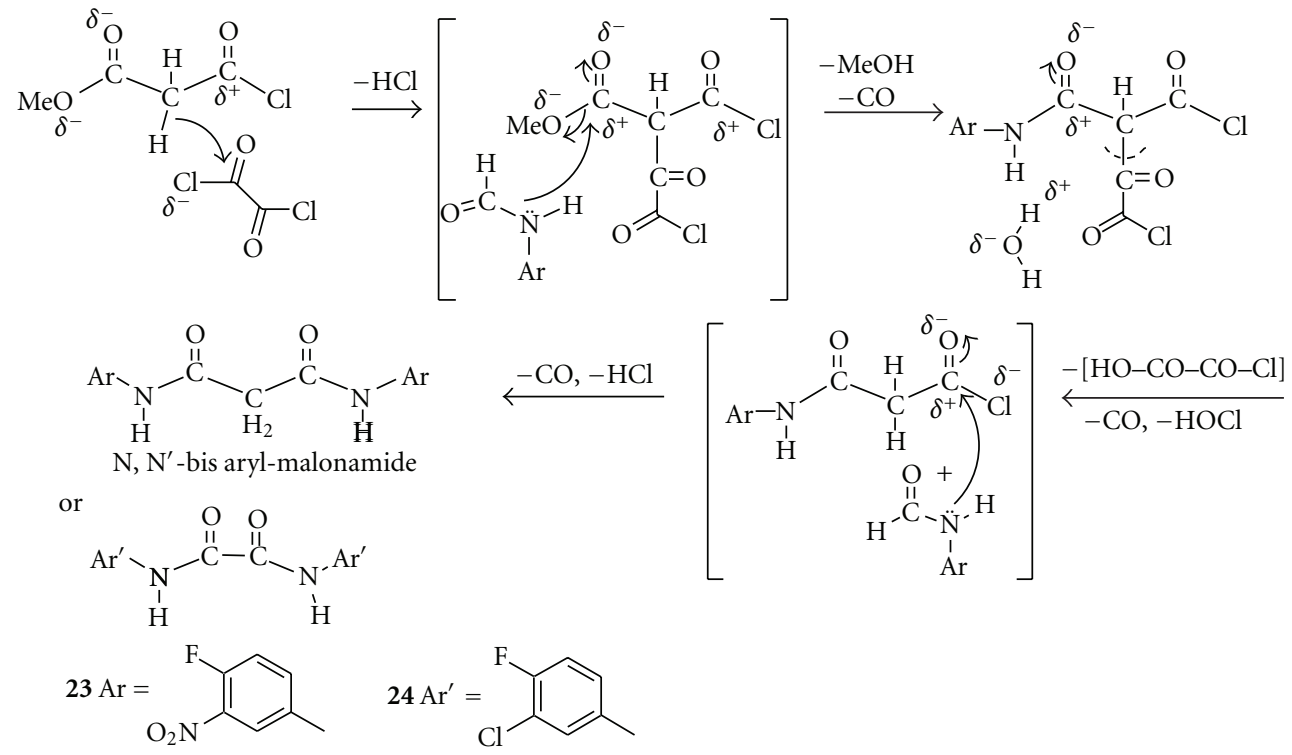

Scheme 4: A possible formation of $N, N^{\prime}$-bis-Aryl malonamide instead of norfloxacin analogues.

Fungi: Candida Albicans (C.A.); Aspergillus Funigates (A.F.). The presterilized filter paper disks $(6 \mathrm{~mm}$ diameter $)$ were impregnated with 30,40 , and $50 \mu \mathrm{g}$ of the compound and dissolved in DMF as solvent, which has no effect on either bacteria or fungi. These disks were implanted on different sets of agar plates containing the microbes. The agar plates were then incubated for 24 hours at $37^{\circ} \mathrm{C}$ for bacteria and for 7 days at $28^{\circ} \mathrm{C}$ for fungi. Nalidixic acid and nystain were used as reference antibiotics.

In addition, similar antimicrobial assay was performed for the biologically highly active compounds $20,21,11,23$, and 12 after exposure of the Petridishes containing microorganisms and the test compounds to UV light $(\lambda 366 \mathrm{~nm})$ for 3 hours before the incubation.

\section{Results and Discussion}

3.1. Synthesis of Novel Norfloxacin Analogues. In the present study, novel norfloxacin analogues were synthesized using basically the Vilsmeier method with some modifications. The 7-bromo-6-N-benzyl piperazinyl-4-oxoquinoline-3-carboxylic acid (12) was isolated at high temperature (mention the temperature). On the other hand, bis-compounds $N, N^{\prime}$ bis-(4-fluoro-3-nitrophenyl)-oxalamide and $N, N^{\prime}$-bis-(3chloro-4-fluorophenyl)- malonamide (22) and (23) were obtained under reveres Vilsmeier approach using the modified method of commercially available Merrifield resin 14, which was modified by introduction of spacer with free hydroxyl group to enhance the activity of the substrates bound to the polymer. Besides the determination of their physiochemical properties, these compounds were evaluated for use in vitiligo and as antimicrobial agents.

Isolation of two novel $N, N$-bis-(aryl) compounds 23, 24 instead of norfloxacin analogue targets could be due to a type of interaction between oxalyl chloride with methyl malonyl chloride followed by monoacylation of anilidimide which hinders the formation of norfloxacin analogues via a second interaction with other anilidimide molecule (Scheme 4). Recently, nonfluorinated N, N-bis-aryl derivative was reported as an HIV-1 integrase inhibition [19].

\subsection{Physiochemical Properties}

3.2.1. Lipophilicity. The lipophilic and Zwitterionic form of the obtained compounds, as well as steric and electronic effects or charge density, plays an important role for chemical and biocidal activities. $N$-Mannich base functional group can increase the lipophilicity of the tested compounds, for example, 12 at physicobiological $\mathrm{pH}$ values by decreasing their protonation resulting in the enhancement of absorption through biomembranes. It is clear that the neutral species of haloquinolones are more lipophilic than Zwitter ionic form. In addition, steric and electronic effects or molecular charge density can affect lipophilicity (Scheme 5).

3.2.2. Fourier Transforms Infrared Spectroscopy. Generally, Fourier transforms infrared spectroscopy (FT-IR) studies of the obtained compounds in both the solid and solution $\left(\mathrm{CHCl}_{3}\right)$ states showed lack of some characteristic bands in the solution state, for example, compound 12 (Figure 2). This effect may be due to a type of intramolecular and/ or intermolecular H-bonding between functional group of the tested compounds and a functional group in the solvent used, which possibly act similarly to the functional groups of the organisms leading to inhibition of their vital activities and death. The results of the Fourier transform infrared spectroscopy are given in Figure 1. 


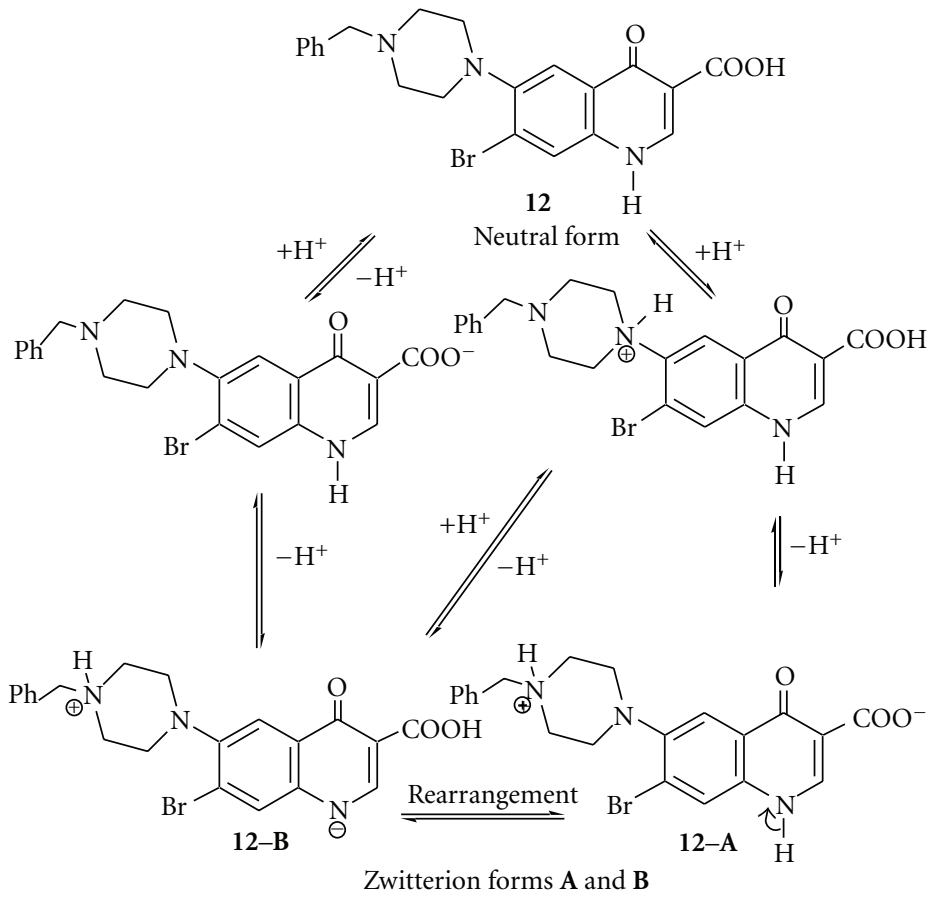

Scheme 5

3.2.3. Other Physicochemical Properties of Highly Bioactive Compounds. The physicochemical properties of highly bioactive pure tested compounds are demonstrated as follows.

(a) Melting Points. They differ according to the type of solvent from which crystals are obtained, for example, compound 20 had approximately $87^{\circ} \mathrm{C}$ for pure crystallized from cyclohexane, and $90^{\circ} \mathrm{C}$ from chloroform.

(b) Solubility in Water. Pure compound 20, for example, gave approximately, $200 \mu \mathrm{g} / \mathrm{L}$ while compound 23 showed $350 \mu \mathrm{g} / \mathrm{L}$ at $20^{\circ} \mathrm{C}$.

(c) Pka. Pure tested compounds at pH 5.7 and 9 at $24^{\circ} \mathrm{C}$ showed different types of protons, in quinolone the $\mathrm{COOH}$ and $\mathrm{NH}$, while in the formylamino derivative, $-\mathrm{COOH},-\mathrm{CHO}$, and $\mathrm{NH}$. This data indicated that tested compounds $20,21,11,23$, and 12 have a very low rate of hydrolysis because of its stability in suspension concentration under normal conditions Table 4.

3.3. Antimicrobial Assay. The potentialities of the tested compounds 19, 20, 21, 9, 11, 23, and 12 are given in Tables 1,2 and 3 .

3.4. Photochemical Probe Agents. Vitiligo is an acquired disorder characterized by patchy progressive depigmentation of the skin. It affects about $2 \%$ of world population. Vitiligo occurs equally in both sexes and has no age limits. It may be presented as a single path, which may be progressing or static for a long time and suddenly starts progressing or multiple patches, which are slowly progressing or stationary indefinitely. These depigmented molecules sometimes spontaneously pigment and depigment again and are often symmetrical and are called as vitiligo vulgarize. The etiology of nonsymmetrical Vitiligo, namely, segment vitiligo, is entirely different from symmetrical vitiligo. Often the exposed areas of the skin and areas around orifices of the body are depigmented rather than other areas [20]. The melanocytes successfully treated vitiligo patients by PUVA therapy [21]. Increasing use of PUVA-8MP could be responsible for a type of skin cancer [22]. Thus, some antibiotics like nalidixic acid and Nystatin are now used to control the vitiligo symptoms.

\section{Acknowledgments}

The authors would like to thank Professor O. Meth-Cohen, Professor P. Groundwater, Professor R. Anderson, and Dr. Amal Alkordy from Sunderland University, UK. Thanks are extended to Professor Zenib M. ElBaza and coworkers, Department of Pharmaceutical Microbiology, National Center for Radiation Research and Technology, Nasr City, Egypt. The authors are also grateful to the Deanship Research, King Abdul-Aziz University, Jeddah, Saudi Arabia, for the financial support.

\section{References}

[1] J. S. Wolfson and D. C. Hooper, "Fluoroquinolone antimicrobial agents," Clinical Microbiology Reviews, vol. 2, no. 4, pp. 378-424, 1989.

[2] M. P. Wentland, D. M. Bailey, J. B. Cornett, R. A. Dobson, R. G. Powles, and R. B. Wagner, "Novel amino-substituted 
3-quinolinecarboxylic acid antibacterial agents: synthesis and structure-activity relationships," Journal of Medicinal Chemistry, vol. 27, no. 9, pp. 1103-1108, 1984.

[3] S. Atarashi, M. Imamura, Y. Kimura, A. Yoshida, and I. Hayakawa, "Fluorocyclopropyl quinolones. 1. Synthesis and structure-activity relationships of 1-(2-fluorocyclopropyl)3-pyridonecarboxylic acid antibacterial agents," Journal of Medicinal Chemistry, vol. 36, no. 22, pp. 3444-3448, 1993.

[4] P. Selvam, P. Rathore, S. Karthikumar et al., "Synthesis and antiviral studies of novel N-sulphonamidomethyl piperazinyl fluoroquinolones," Indian Journal of Pharmaceutical Sciences, vol. 71, no. 4, pp. 432-436, 2009.

[5] T. E. Albertson, N. C. Dean, A. A. El Solh, M. H. Gotfried, C. Kaplan, and M. S. Niederman, "Fluoroquinolones in the management of community-acquired pneumonia," International Journal of Clinical Practice, vol. 64, no. 3, pp. 378-388, 2010.

[6] R. Stahlmann and H. Lode, "Safety considerations of fluoroquinolones in the elderly: an update," Drugs \& Aging, vol. 27, no. 3, pp. 193-209, 2010.

[7] S. Bazile, N. Moreau, D. Bouzard, and M. Essiz, "Relationships among antibacterial activity, inhibition of DNA gyrase, and intracellular accumulation of 11 fluoroquinolones," Antimicrobial Agents and Chemotherapy, vol. 36, no. 12, pp. 2622 2627, 1992.

[8] L. J. V. Piddock, Y. F. Jin, and D. J. Griggs, "Effect of hydrophobicity and molecular mass on the accumulation of fluoroquinolones by Staphylococcus aureus," Journal of Antimicrobial Chemotherapy, vol. 47, no. 3, pp. 261-270, 2001.

[9] M. Bermejo, V. Merino, T. M. Garrigues et al., "Validation of a biophysical drug absorption model by the PATQSAR system," Journal of Pharmaceutical Sciences, vol. 88, no. 4, pp. 398-405, 1999.

[10] P. A. Procopiou, R. A. Ancliff, M. J. Bamford et al., "4-Acyl1-(4-aminoalkoxyphenyl)-2-ketopiperazines as a novel class of non-brain-penetrant histamine $\mathrm{H}_{3}$ receptor antagonists," Journal of Medicinal Chemistry, vol. 50, no. 26, pp. 6706-6717, 2007.

[11] A. Foroumadi, L. Firoozpour, S. Emami et al., "Synthesis and antibacterial activity of $\mathrm{N}$-[5-(chlorobenzylthio)-1,3,4thiadiazol-2-yl] piperazinyl quinolone derivatives," Archives of Pharmacal Research, vol. 30, no. 2, pp. 138-145, 2007.

[12] O. Meth-Cohn and D. L. Taylor, "The reverse vilsmeier approach to the synthesis of quinolines, quinolinium salts and quinolones," Tetrahedron, vol. 51, no. 47, pp. 12869-12882, 1995.

[13] J. F. Bunnett and M. M. Rauhut, "The von Richter reaction. III. Substituent effects," Journal of Organic Chemistry, vol. 21, no. 9, pp. 934-938, 1956.

[14] F. D. Bellamy and K. Ou, "Selective reduction of aromatic nitro compounds with stannous chloride in non acidic and non aqueous medium," Tetrahedron Letters, vol. 25, no. 8, pp. 839$842,1984$.

[15] K. G. Liu and A. J. Robichaud, "A general and convenient synthesis of N-aryl piperazines," Tetrahedron Letters, vol. 46, no. 46, pp. 7921-7922, 2005.

[16] A. Leonardi, D. Barlocco, F. Montesano et al., "Synthesis, screening, and molecular modeling of new potent and selective antagonists at the $\alpha$ adrenergic receptor," Journal of Medicinal Chemistry, vol. 47, no. 8, pp. 1900-1918, 2004.

[17] J. R. Hauske and P. Dorff, "A solid phase CBZ chloride equivalent-a new matrix specific linker," Tetrahedron Letters, vol. 36, no. 10, pp. 1589-1592, 1995.

[18] "World of Microbiology and Immunology "Agar Diffusion.,"” May 2010, http://www.encyclopedia.com/.
[19] M. Sechi, U. Azzena, M. P. Delussu et al., "Design and synthesis of bis-amide and hydrazide-containing derivatives of malonic acid as potential HIV-1 integrase inhibitors," Molecules, vol. 13, no. 10, pp. 2442-2461, 2008.

[20] R. B. Goudie, M. Soukop, J. H. Dagg, and F. D. Lee, "Hypothesis: symmetrical cutaneous lymphoma," The Lancet, vol. 335, no. 8685, pp. 316-318, 1990.

[21] N. Puri, M. Mojamdar, and A. Ramaiah, "Growth defects of melanocytes in culture from vitiligo subjects are spontaneously corrected in vivo in repigmenting subjects and can be partially corrected by the addition of fibroblast-derived growth factors in vitro," Archives of Dermatological Research, vol. 281, no. 3, pp. 178-184, 1989.

[22] B. Bridges and G. Strauss, "Possible hazards of photochemotherapy for psoriasis," Nature, vol. 283, no. 5747, pp. 523-524, 1980. 


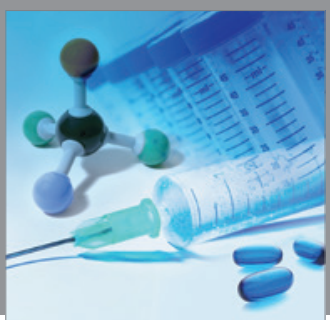

International Journal of

Medicinal Chemistry

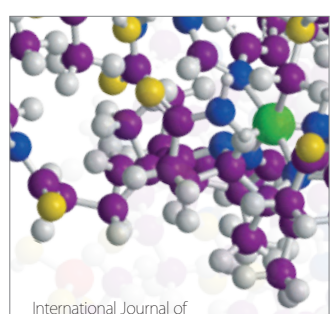

Carbohydrate Chemistry

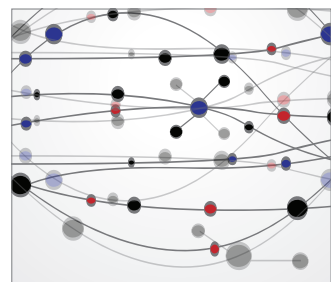

The Scientific World Journal
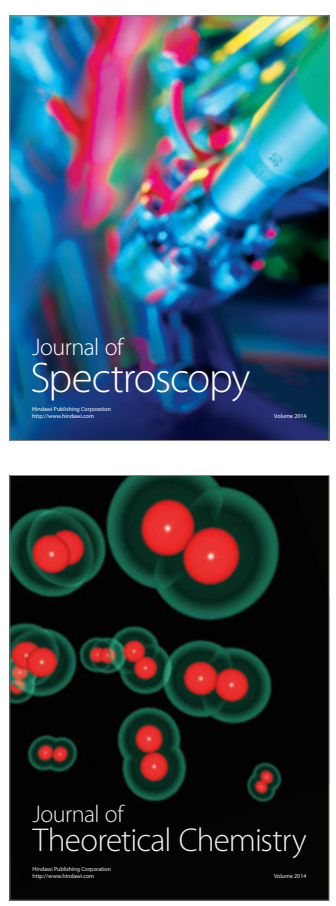
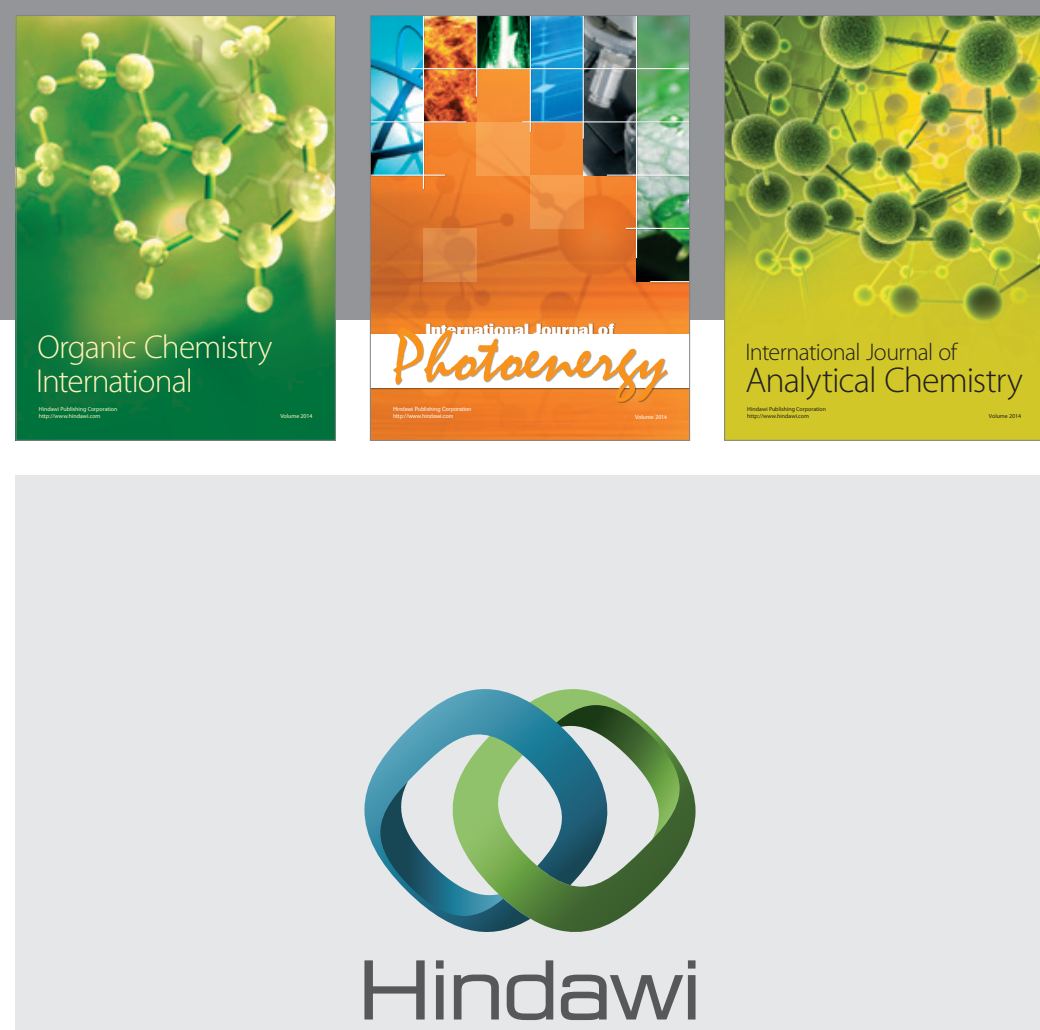

Submit your manuscripts at

http://www.hindawi.com
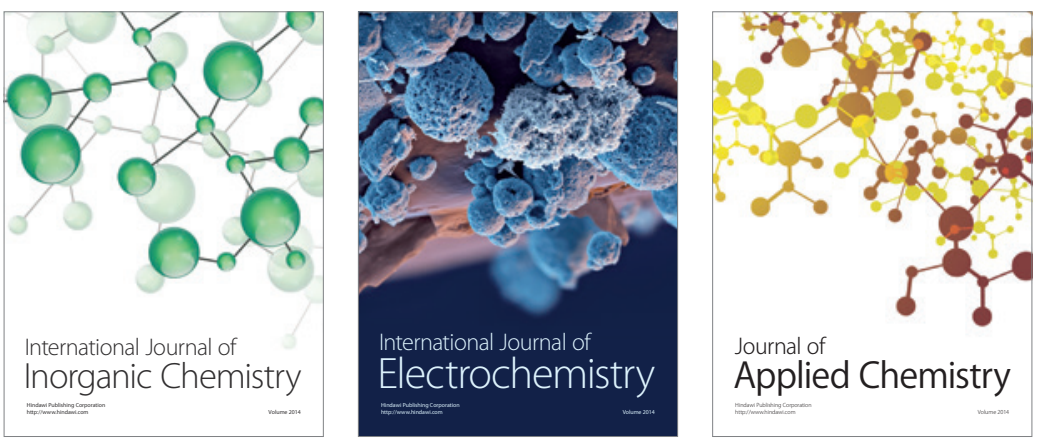

Journal of

Applied Chemistry
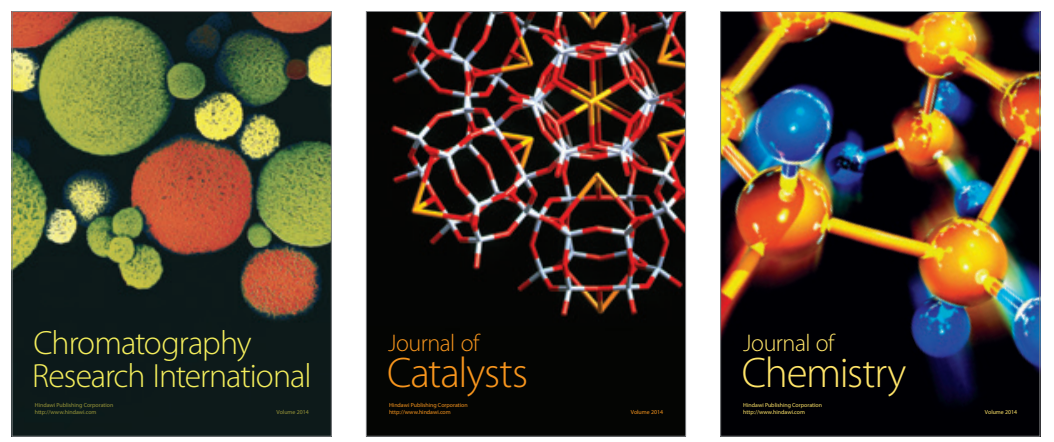
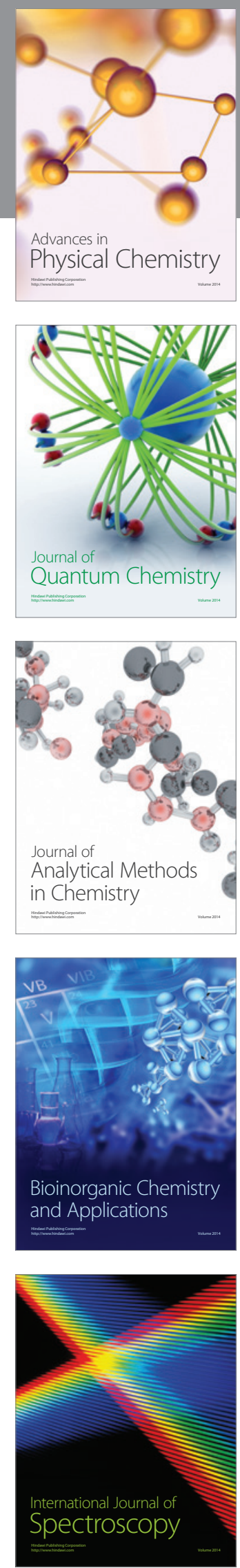